\title{
34.2. MIOCENE AND QUATERNARY SILICOFLAGELLATES IN SEDIMENTS FROM THE MEDITERRANEAN SEA
}

\author{
Paulian Dumitrica, Geological Institute, Bucharest, Romania
}

\section{INTRODUCTION}

Contrary to all expectation, it was not possible to find in the Mediterranean Sea Basin, the same more or less continuous Miocene-Pliocene-Quaternary silicoflagellate sequence as was found for foraminifera and nannoplankton. A general characteristic of the silicoflagellate deposits cored on this leg is their very short vertical extent. This is due to the frequent changes within the marine realm of the Mediterranean Sea during the (?) upper Miocene and Quaternary. For this reason, a biostratigraphic correlation and zonation of the silicoflagellate-bearing sediments was possible only for the Quaternary, where somewhat longer sequences of sedil ents with siliceous microplankton were obtained.

The material used for this report is from some of the cores recovered at Sites 124, 127 and 128, where silicoflagellates occur in sufficient numbers. They have also been recorded in a few cores from Sites 121, 129, 130 and 134 , but are so infrequent at these sites that they have been omitted from consideration.

\section{MIOCENE SILICOFLAGELLATES, SITE 124}

The only Miocene silicoflagellates found were at this site, in moderate numbers, in Sample 13-124-13-2, 89-90 $\mathrm{cm}$. Their occurrence at other levels of the same section, where diatoms and ebridians are present, is extremely rare.

The silicoflagellates are present within the diatomaceous marls occurring at the base of the cored evaporitic series. The species and their frequency are shown in Figure 1.

The assemblage is dominated by Distephanus speculum, the members of which are characterized by a wide range of variation. This denotes an environmental instability that is normal for this realm of evaporitic sedimentation with sporadic contributions of marine waters. Three other

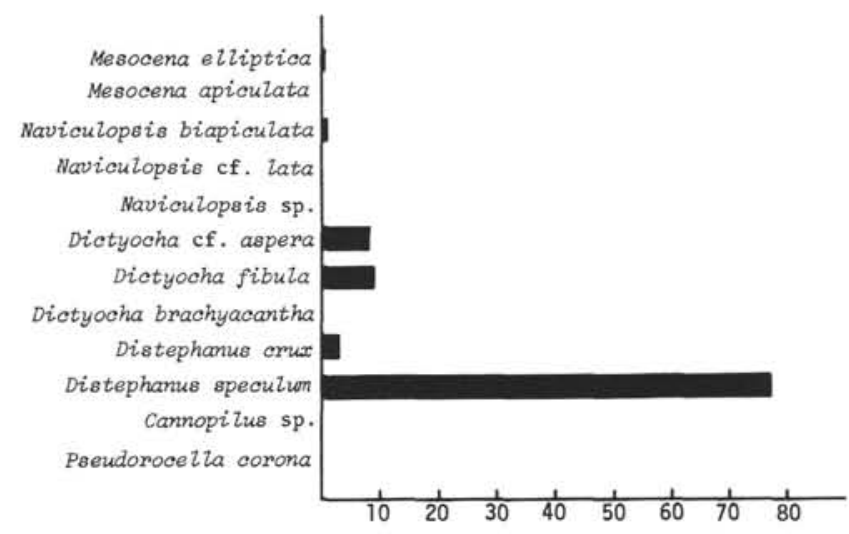

Figure 1. Relative frequency of the silicoflagellates in the Miocene Sample 124-13-2, 89-90 cm.
species-Dictyocha cf. aspera, D. fibula and Distephanus crux-appear with a frequency of a few per cent, whereas all other species occur as fractions of a per cent, or only as one or two specimens.

To judge by its composition, this silicoflagellate assemblage is doubtless autochthonous, its species (except Naviculopsis) being frequent in the middle or upper Miocene. The occurrence of the three species of Naviculopsis, particularly $N$. biapiculata, which is known as a Paleogene species, is interesting. However they are not reworked, as one might suppose, because no other Paleogene species of silicoflagellates, nor of ebridians, were recorded in this assemblage.

\section{QUATERNARY SILICOFLAGELLATES SITES 127 AND 128}

Our knowledge of Quaternary silicoflagellates is especially due to recent oceanographic researches (Muhina, 1969; Jousé, 1969; Hays et al., 1969; Ling, 1970). The new data obtained by these investigators have shown the real value of the silicoflagellates for Quaternary stratigraphy.

For the most part, the Quaternary silicoflagellate assemblages resemble those of the living forms, as listed by Deflandre (1950, p. 41): Dictyocha fibula with its varieties typica, aculeata, messanensis, stapedia; Distephanus speculum with its varieties typica, regularis, varians; and $D$. octonarius. They represent the background to some important events that, by their generality and synchronism, acquire a considerable value for the stratigraphy of Quaternary marine sediments.

Certainly the most important event is a short occurrence of Mesocena elliptica, a species generally known as Oligo-Miocene. Jousé (fide Jousé, 1969) and Muhina (fide Ling, 1970) reported recognizing this occurrence in 1963 in two sediment cores from the equatorial Pacific. Recently, Jousé (1969) recorded this strange reappearance in other cores from the same area, and Muhina (1969) found it in both equatorial Pacific and Indian Ocean sediments. Both authors speak of the synchronism of the occurrences of $M$. elliptica in the Quaternary sediments. When did it take place?

On the basis of diatoms and silicoflagellates, Muhina (loc. cit.) divided the Quaternary sediments into eight horizons, four corresponding to glacial ages (horizons 2, 4, $6,8)$ and four to interglacials including the postglacial (horizons $1,3,5,7$ ). She compared the paired horizons with the four glaciations of North America. According to both Muhina and Jousé, who use similar biostratigraphic subdivisions, the occurrence of $M$. elliptica took place in the upper part of the middle Pleistocene, more exactly in the upper half of horizon IV, the upper limit of this occurrence corresponding generally to the boundary between horizons IV and III. 
Hays et al. (1969) recorded M. elliptica from the same equatorial zone of the Pacific Ocean, and stated that it "brackets the Jaramillo event for which it is a useful guide fossil". It seems reasonable to suppose that the occurrences of $M$. elliptica in the cores investigated by Muhina and by Jousé on the one hand, and by Hays et al. on the other, are synchronous because they come from the same area, and also that the ranges of some diatoms (such as Rhizosolenia praebergonii and Thalassiosira convexa, two guide species) are similar in all investigated cores. It follows that Muhina's horizon IV is roughly correlative with the interval between the Olduvai event and the base of the Brunhes normal epoch. Because the boundary between the Quaternary and Pliocene passes through the Olduvai event, only Muhina's horizons I-IV, and possibly the uppermost part of her horizon V, are Quaternary, the others (V-VIII) belong to the Pliocene. This correlation is in agreement with the distribution of the radiolarians and nannoplankton (Ling, 1970 , p. 115). This attempt at correlation between paleomagnetic stratigraphy and biostratigraphy is presented in Figure 2. The correlation recently suggested by Jousé (1969, fig. 2) is wholly erroneous, and will not be discussed here.

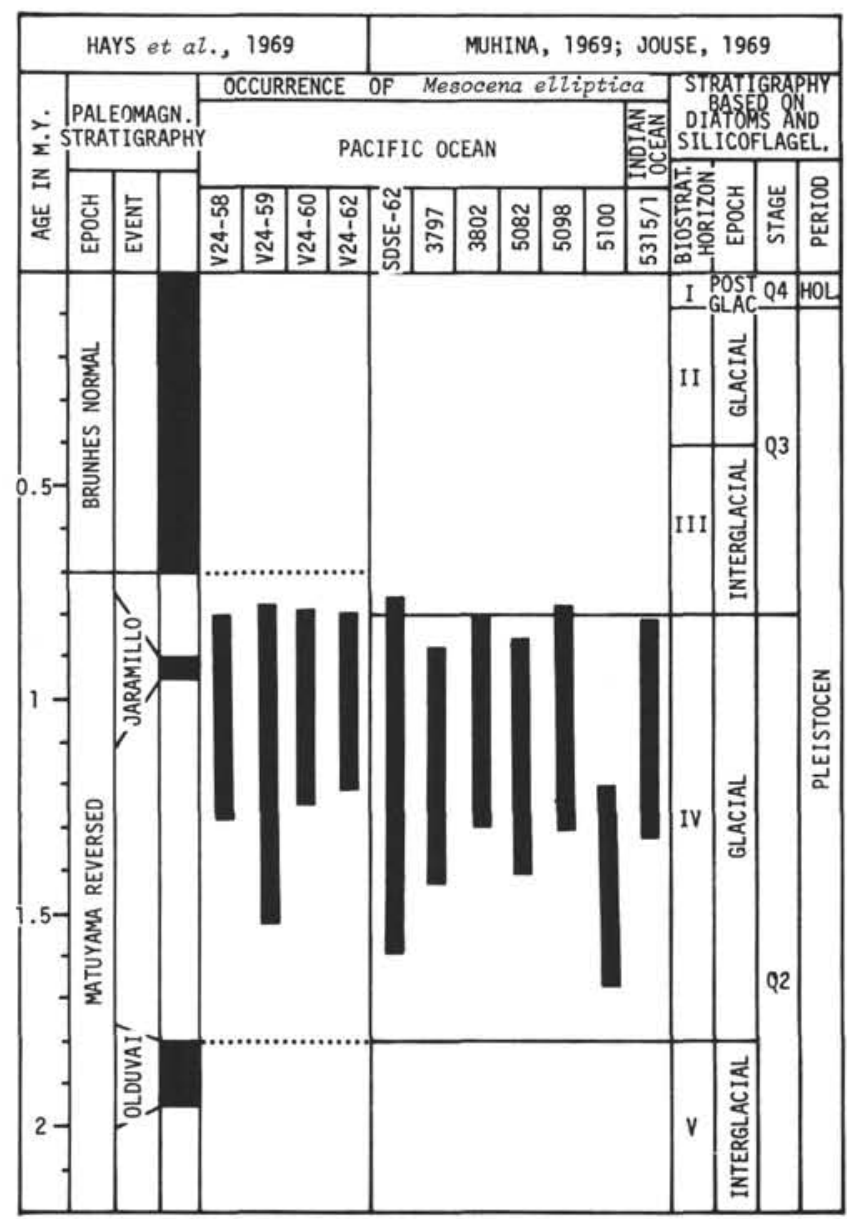

Figure 2. Occurrence of Mesocena elliptica in Pacific and Indian Oceans Quaternary sediments, and correlation by means of it between paleomagnetic stratigraphy and biostratigraphy based on diatoms and silicoflagellates.
A very important study of Quaternary silicoflagellates, from both taxonomic and stratigraphic points of view, was recently published by Ling (1970). He recognized, on the basis of several cores recovered from the central North Pacific sediments (between $33^{\circ} 26^{\prime} \mathrm{N}$ and $42^{\circ} 36^{\prime} \mathrm{N}$ ), that "disappearance of M. elliptica is geologically isochronous at low and middle latitudes of the North Pacific". It is also interesting to note that the last extinction of $M$. elliptica coincides, according to Ling's data, with those of $D$. subarctios and $D$. cf. ausonia.

As we have already shown, in the Mediterranean Sea Basin, Quaternary silicoflagellates were found only in a few cores from Sites 127 and 128. Their occurrence, as well as that of other siliceous microfossils, is tried to the levels of sapropelitic sediments. On the basis of some species of silicoflagellates and ebridians, the sapropelitic levels of the two sites can be easily correlated, and this correlation agrees with that based on nannoplankton.

The following species were recorded from the two sites: Mesocena elliptica Ehr., Dictyocha fibula Ehr., D. aculeata Lemm., D. messanensis Hck., D. brachyacantha n. sp., $D$. cf. aspera Lemm., D. lingi n. sp., Distephanus speculum (Ehr.), D. octogonus (Ehr.). Their occurrence and frequency at each level of the cored Quaternary sediments at Sites 127 and 128, is given in Figures 3 and 4. This list is rather similar to that established by Ling for Quaternary sediments from the central North Pacific. An additional point of similarity is the short-ranging reappearance of $M$. elliptica, and its simultaneous extinction with that of $D$. lingi (D. cf. ausonia, sensu Ling). D. fibula, D. lingi, $D$. aculeata, Distephanus speculum, and M. elliptica are common to the Quaternary of the Mediterranean Sea basin and to the North Pacific. The Pacific species Dictyocha subarctios, Distephanus octangulatus, D. cf. stauracanthus, and $D$. speculum (sensu Ling) are missing in the cores recovered from the Mediterranean Sea, but the latter contain Dictyocha messanensis (not D. messanensis sensu Ling) and Distephanus octogonus, the former being very frequent $(50-90 \%)$.

Mesocena elliptica was recorded with a frequency up to 36 per cent in Cores 10 and 11 of Site 128 , between 415 to 455 meters below the sea floor. As the coring terminated at 455 meters, the time of reappearance of this species in the Quaternary of the Mediterranean Sea cannot be established. It is known that $M$. elliptica disappears somewhere within the interval between Core 8 (the first upper core containing silicoflagellates) and Core 10, namely, between 315 to 415 meters.

At Site 127, neither of the two mentioned index species, $M$. elliptica or $D$. lingi, was recorded. Their absence is due to the shorter Quaternary sequence cored at this site; the lowermost core containing silicoflagellates (127-14) being correlated roughly with Core 8 of Site 128 .

The occurrence of $M$. elliptica in the Quaternary sediments of the Mediterranean Sea raises a problem concerning its isochronism or heterochronism as compared with its occurrence in the Pacific and Indian Oceans. In my opinion there is no compelling argument against the assumption of isochronism of this species from the Pacific to the Mediterranean Sea. Its general occurrence in the Quaternary Pacific and Indian Ocean sediments, and the 


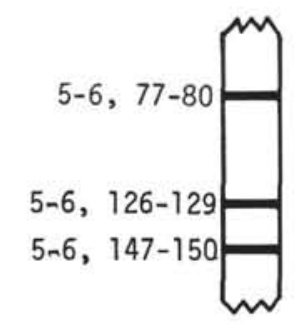

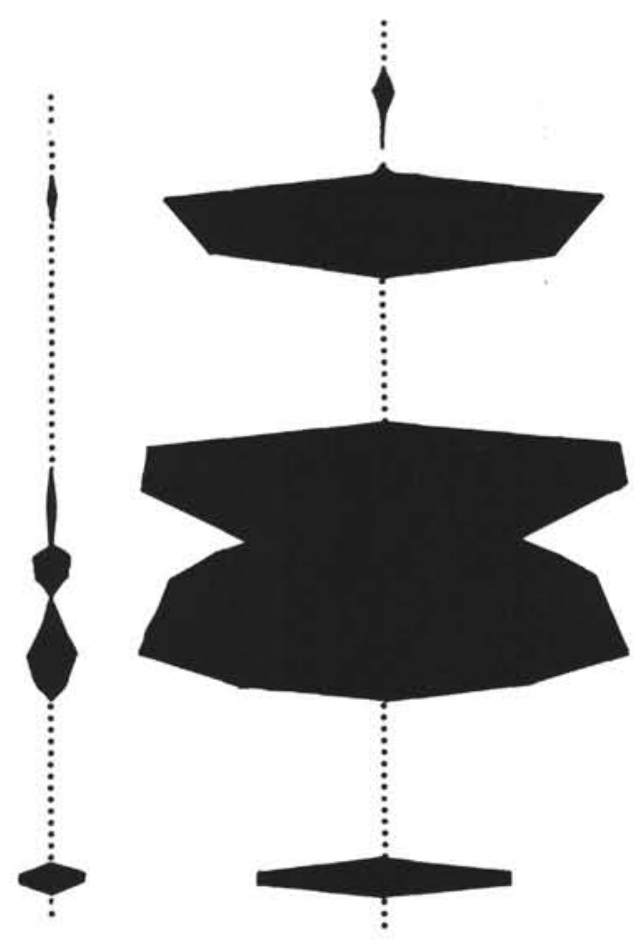

D. fibuza

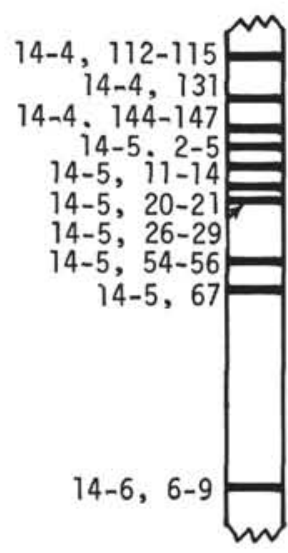

D. messanensis

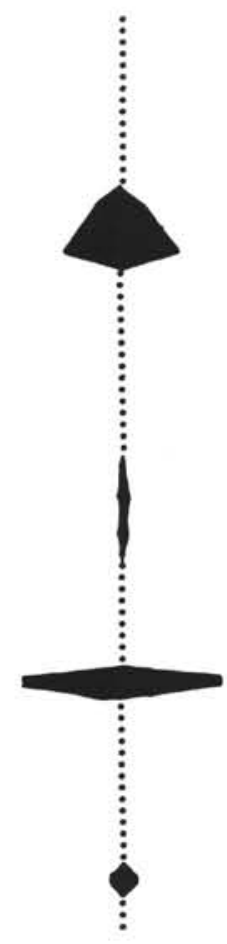

D. aculeata

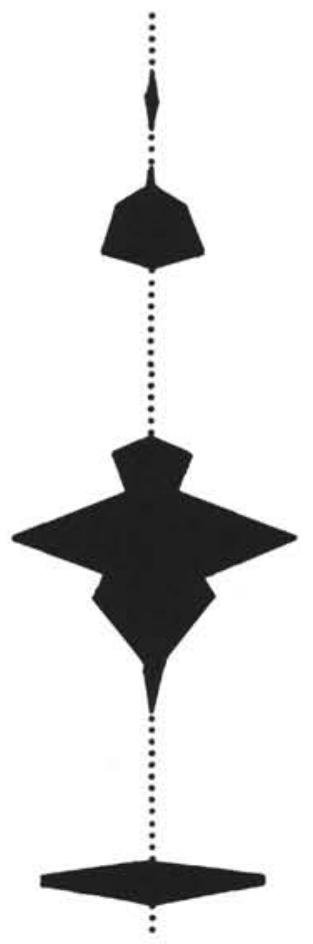

$\vdots$

D. speculum D. octogonus

Figure 3. Relative frequency of the silicoflagellates in the Quaternary cores at Site 127.

simultaneous extinction of $M$. elliptica and $D$. lingi in both the Pacific and Mediterranean Sea, are the main arguments in favor of such a correlation.

\section{SYSTEMATICS}

As the systematics of the silicoflagellates is not yet sufficiently elucidated, particular attention is paid in this chapter to some systematic and taxonomic problems raised by the investigated material. Determination of the biostratigraphic value of each species depends to a great extent upon the solution of these problems.

\section{Family DICTYOCHIDAE (Lemmermann) Genus MESOCENA Ehrenberg}

Mesocena elliptica Ehrenberg

(Plate 1, Figures 1 to 6; Plate 2, Figures 1 to 6; Plate 3, Figures 1, 3 to 6 )

Mesocena elliptica Ehrenberg, 1854, Plate 20, Figure 44; Deflandre, 1932 a, p. 497 , Figures 21 to 26 ; Stradner, 1961 , p. 89 , Plate 1 , Figures 34 to 38; Bachmann and Ichikawa, 1962, p. 167, Plate 1, Figures 1 to 10; Plate 9, Figures 1 to 7 ; Bachmann et al., 1963, p. 151 , Plate 18, Figures 46 to 53, Plate 19, Figures 54 to 59 ; Plate 21, Figures 4 to 8; Gleser, 1966, p. 283, Plate 30, Figures 1 to 5 ; Mesocena cf. elliptica Ling, 1970, p. 100, Plate 20, Figures 8 to 14 .

Remarks: Two occurrences of this large species have been recorded in the cores recovered during Leg 13. One is in the Miocene (upper Miocene?) from Site 124 (sample 124-13-2, 89-90 $\mathrm{cm}$ ), and the other is in the Quaternary from Site 128 (cores $128-10-3,0-150 \mathrm{~cm}$, and $128-11-3,148-150 \mathrm{~cm})$. A single hornless specimen was also found at Site 127 (sample 127-14-5, 20-21 cm) (see Plate 2, Figure 6).

In the Miocene cited, its frequency is quite insignificant. On the contrary, it is rather high (up to $36 \%$ ) in the Quaternary (Pleistocene), for which it is a good marker fossil. In agreement with
Ling (1970), this late occurrence of the species is not due to reworking from older, presumably Miocene sediments. If this had been so, it should have been accompanied by other Miocene silicoflagellate and ebridian species. In our material, $M$. elliptica is associated only with Quaternary forms. It is, however, true that some species accompanying it (for example Dictyocha brachyacantha, $D$. cf. aspera and $D$. lingi) have a Miocene aspect, but (a) the superficial ornamentation of the Pleistocene forms of the first species is not of Miocene type, (b) the last species has hitherto been found only in the Pleistocene, and (c) the second is probably a simple variant of $D$. lingi. In addition, synchronous reworking on a world-wide scale (Pacific and Indian Oceans, and Mediterranean Sea) would be very difficult to explain.

There is, as Ling remarked, a certain difference between the Miocene and the Quaternary specimens. The latter is generally rectangular rather than elliptical, is smoother and somewhat irregularly granulate, and is larger in size in contrast to the former. The variation criteria is only partially true and not at all a rule, particularly for the Mediterranean specimens. All intermediate forms between those with two and five radial horns, and between those which are elliptical and quadrangular, have been recorded in both Miocene and Quaternary specimens. I believe that a much more important characteristic for most specimens of Quaternary age is their very particular superficial ornamentation which is formed not of small spines united by crests in a reticulate network as in most Miocene specimens, but of sparse warts, generally transversely disposed. However, the same type of ornamentation seems to characterize some Miocene specimens found in both 124-13-2 at $89-90 \mathrm{~cm}$ (see Plate 2, Figure 1, the only Miocene specimen bearing this ornamentation), and in Pacific sediments (see Ling, 1970, Plate 20 , Figures 8 to 12 ). Deflandre (1932b, Figure 6) also illustrated a rather similar ornamentation on a Miocene specimen from Moron (Spain). Unfortunately, we do not know yet to what extent this peculiarity of the superficial ornamentation of $M$. elliptica has taxonomic value. The differences might be of an ecological nature, because not only the Quaternary specimens of $M$. elliptica seem to possess such a simple superficial ornamentation, but also a series of 

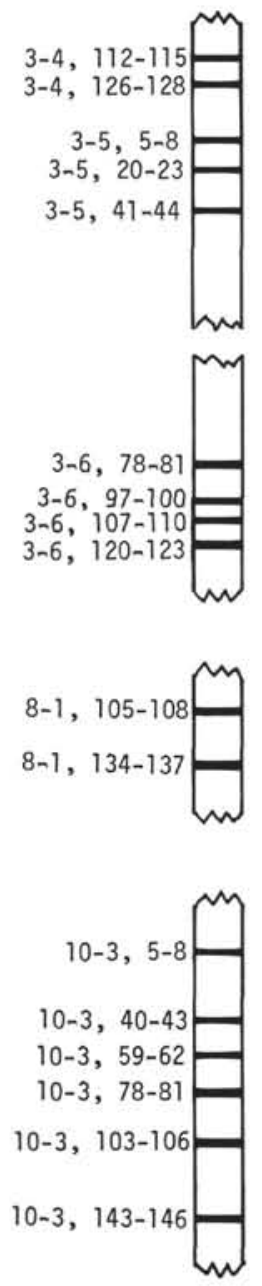

$11-3,148-150$

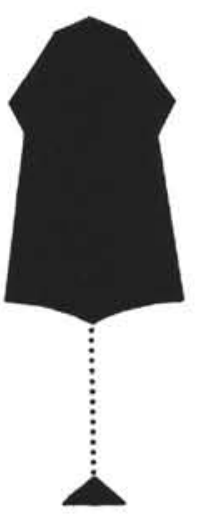

M. elliptica

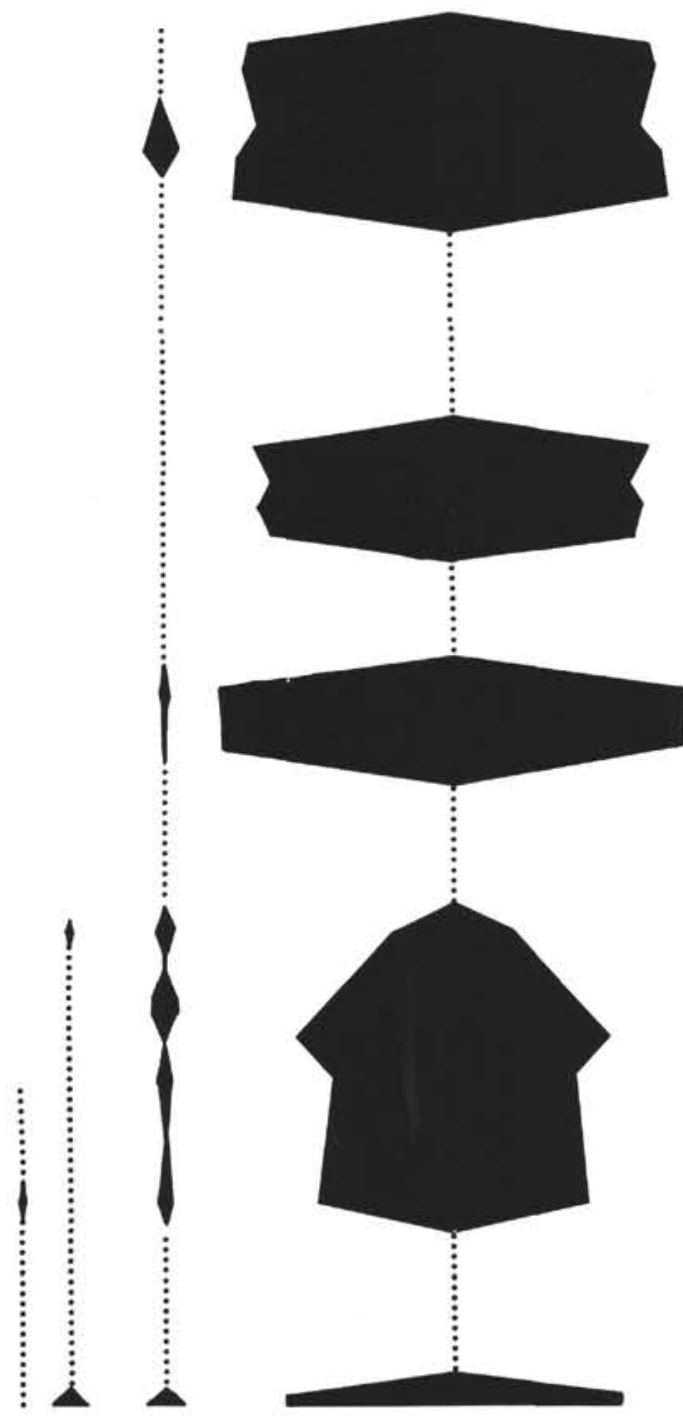

D. messanensis

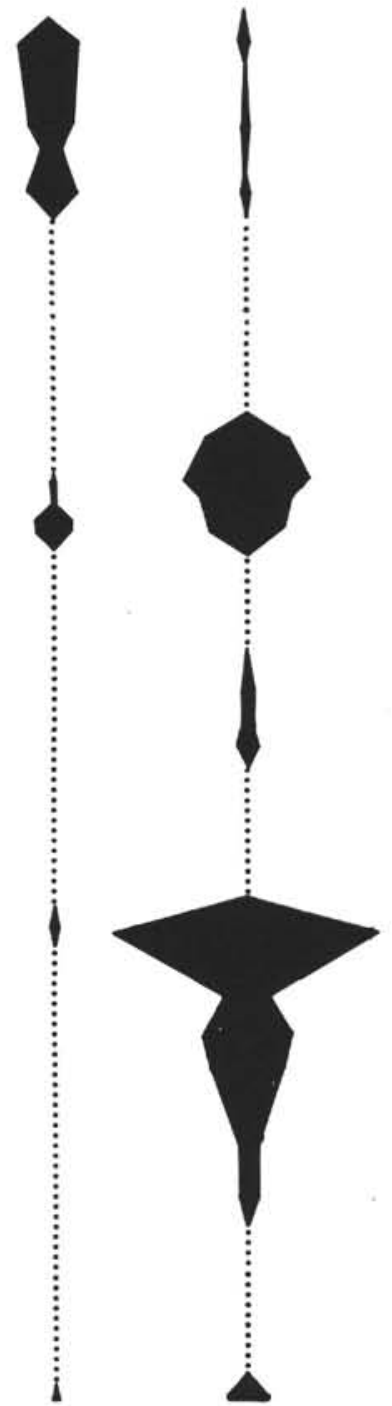

D. aculeata

D. speculum

D. brachyacantha

Figure 4. Relative frequency of the silicoflagellates in the Quaternary cores at Site 128.

Quaternary representatives of other species. However, the ornamentation of most Pleistocene specimens of $M$. elliptica is so characteristic, and so different from the reticulation of the Miocene or older forms, that it probably characterizes an independent taxon of subspecific rank-Mesocena elliptica verrucosa $\mathrm{n}$. subsp., having as holotype the specimen illustrated in Plate 3, Figure 3, and coming from 128-10-3, 143-146 cm. Its diagnosis would be, in short, the following: basal ring similar in shape and size to $M$. elliptica s. str., but with a superficial ornamentation consisting only of sparse warts. The hornless specimen illustrated in Plate 2, Figure 1, coming from the Miocene at 124-13-2, $89-90 \mathrm{~cm}$, probably belongs to the same subspecies. Its occurrence at this level is, at least in view of available data on the Miocene silicoflagellates of the Tethys Basin, very strange. In addition, the Miocene sample investigated contains two subspecies of $M$. elliptica: (a) M. elliptica elliptica Ehr. (Plate 3, Figure 4), with four radial horns and a reticulate ornamentation, and (b) M. elliptica diodon Ehr. (Plate 1, Figure 3), with only two radial horns and an ornamentation consisting (as far as it is possible to see with an optical microscope) of transverse ridges. The Quaternary specimens with two axial horns, in my opinion, do not belong to this subspecies. They are only simple variants of the ordinarily four-horned subspecies because they have a superficial ornamentation similar to the latter.

\section{Mesocena apiculata (Schulz) Deflandre \\ (Plate 3, Figure 2)}

Mesocena apiculata Deflandre, 1932a, p. 449, Figures 34 to 35; Tynan, 1957, p. 134, Plate 1, Figure 10; Stradner, 1961, p. 89, Plate 1, Figures 28 to 29; Bachmann and Ichikawa, 1962, p. 152, Plate 19, Figures 60 to 62 ; Plate 22, Figures 14 to 15; Bachmann, 1964, p. 107, Plate 4, Figure 36; Bachmann, 1970a, p. 280, Plate 5, Figures 10 to 16; Plate 6, Figures 1 to 5; Septamesocena apiculata Bachmann, 1970b, p. 13.

The only representative of this species in the investigated material is the broken specimen illustrated. It was found in the upper (?) Miocene at 124-13-2, 89-90 cm.

\section{Genus NAVICULOPSIS Frenguelli}

\section{Naviculopsis biapiculata (Lemmermann)} (Plate 4, Figures 1, 2)

Dictyocha navicula var. biapiculata Lemmermann, 1901, p. 258 , Plate 10, Figures 14, 15; Schulz, 1928, p. 224, Figures 18, 19; Gemeinhardt, 1930, p. 36, Figures 24a, b; Dictyocha navicula var. biapiculata fa. constricta Gemeinhardt, 1930, p. 38, Figure 25; Naviculopsis biapiculata Frenguelli, 1940, Figures 11c, d; 
Naviculopsis biapiculata var. biapiculata Gleser, 1966, p. 255, Plate 16, Figures 2 to 5.

The illustrated specimens, found in 124-13-2, $89-90 \mathrm{~cm}$, are fairly similar to the Paleogene species $N$. biapiculata. However, I am not quite sure of the identity because of the great difference in age. One could suppose this Miocene occurrence to be due to reworking, but this seems unlikely as indicated above. I rather believe that our knowledge of the stratigraphic range of most species of silicoflagellates, to say nothing of their systematics, is inadequate. I take this opportunity to note that specimens of the same type have been found by G. Deflandre and the author in a Miocene (upper Miocene in Loeblich et al., 1968) diatomite from the Isle of Zante (Greece).

\section{Naviculopsis cf. lata (Deflandre)} (Plate 4, Figure 3)

Dictyocha biapiculata var. lata Deflandre, 1932a, p. 500, Figures 30, 31; Naviculopsis robusta Stradner, 1961, p. 90, Plate 2, Figures 39 to 45 , Naviculopsis lata Bachmann, 1970, p. 278, Plate 2, Figures 1 to 20; Plate 3, Figures 1 to 15 .

Only one specimen of this type was found, in the upper (?) Miocene at 124-13-2, 89-90 cm. It might also belong to Dictyocha ausonia var. regularis Carn., but such an affiliation cannot be proven on the basis of a single specimen.

\section{Naviculopsis sp.}

(Plate 4, Figure 4)

A single specimen of this hornless type was found, in the upper (?) Miocene at $124-13-2,89-90 \mathrm{~cm}$. It is an abnormal form, which possesses an additional lateral bar.

\section{Genus DICTYOCHA Ehrenberg}

Dictyocha brachyacantha n. sp.

(Plate 6, Figures 3, 6; Plate 7, Figures 1 to 3; Plate 5, Figures 6, 7)

Description: Basal ring large, squarish or slightly thombic, armed with four short and almost equal radial horns, the point of which is usually blunt. Apical apparatus generally low, formed of an apical and four lateral bars, all of almost equal size. Due to the squarish form of the skeleton, the axial or transverse position of the apical bar is sometimes uncertain, but it seems that it is mostly axial, at least for the Quaternary forms. Sustaining spines short or even absent, situated under the point of junction of the lateral bars with the basal ring, or a little to the right or to the left. Surface of the skeleton usually with evident ornamentation consisting of a reticulate network (Miocene specimens), or of small warts (Quaternary specimens).

Holotype: Plate 7, Figure 3, Pleistocene. DSDP, 128-11-3, $148-150 \mathrm{~cm}$

Dimensions: Length of the basal ring without radial horns $70-80 \mu$, with radial horns $82-99 \mu$; width of basal ring without radial horns $70-80 \mu$, with radial horns $80-90 \mu$.

Remarks: Many specimens of this type, coming from various Miocene deposits, have been described under various names by Bachmann $(1963,1964,1967)$. In Leg 13 the species was found in the upper (?) Miocene at Site 124 and in the Quaternary at Site 128. The Miocene specimens are rather similar to those of the Quaternary, except that as in the case of $M$. elliptica, the Quaternary specimens possess a superficial ornamentation formed sometimes of small warts, without a reticulate network of crests.

In the Quaternary at $128-10-3,59-62 \mathrm{~cm}$ and $143-146 \mathrm{~cm}$ there are very rare specimens of irregular shape and with a superficial ornamentation formed only of warts (Plate 5, Figures 6, 7). They are temporarily assigned to $D$. brachyacantha.

Occurrence: Very rare in the upper (?) Miocene of $124 \div 13-2$, $89-90 \mathrm{~cm}$. Rare in Quaternary of $128-11-3,148-150 \mathrm{~cm}$.

Dictyocha lingi n. sp.

(Plate 8, Figures 1 to 7 )

Dictyocha cf. ausonia Ling; 1970 , p. 88, Figures 1 to 3.

Description: Rounded rhombic basal ring armed with four radial horns, the two axial being, as a rule, longer than the other two.
Basal rods arcuate and with denticulate external side. Apical apparatus little raised above the basal ring, and formed of very thin bars; the apical bar is transverse and equal to or a little shorter than the four lateral ones. Usually at the point of junction with the lateral bars the basal ring is more or less constricted. Sustaining spines always present, but migrated on the lateral bars. Surface of the skeleton smooth, except for rare teeth on the external side of the basal ring.

Holotype: Plate 8, Figure 3. Pleistocene. DSDP, 128-11-3, $148-150 \mathrm{~cm}$. Coll. of the Geological Institute, Bucharest.

Dimensions: Length of the basal ring without radial spines $40-43 \mu$, with radial spines $50-56 \mu$; width of basal ring without radial spines $34-38 \mu$, with radial spines $40-46 \mu$.

Remarks: Wholly similar specimens, in both size and shape, have been found by Ling (1970) in Pleistocene sediments from the central North Pacific, and doubtfully assigned to $D$. cf. ausonia. However, although it probably originated from a species of $D$. ausonia or D. fibula var. aspera type, this new species is an independent taxon. This view is supported by the constancy of its features in time and space. D. lingi appears in the Pleistocene beside $M$. elliptica, and disappears with it at the same time, in both North Pacific and Mediterranean sediments. Thus it seems to be a useful guide fossil for the Pleistocene.

I emphasize the very curious position of the sustaining spines on the lateral bars. This represents an important distinctive feature of this species. Such an aberrant position is quite exceptional among the silicoflagellates, being known until now only in the upper Cretaceous species Corbisema geometrica. Certainly, this similarity represents a simple convergence and not the expression of a phylogenetic relationship. It is possible that the migration of the sustaining spines on the lateral bars of this species may be due to the thinness of these bars.

At Site 128, associated with this species appear a few specimens somewhat similar to it, but a little smaller, with thick apical and lateral bars, and with the sustaining spines situated under the point of junction of the lateral bars with the basal ring (Plate 7, Figures 4 to 7). Although doubtfully considered as $D$. cf. aspera, they might represent possible ancestors of $D$. lingi.

Occurrence: In the Mediterranean cores $D$. ling $i$ was found only in $128-10-3,5-8 \mathrm{~cm}$, and $128-11-3,148-150 \mathrm{~cm}$, with a low frequency (up to $7 \%$ ).

\section{Dictyocha fibula Ehrenberg}

(Plate 3, Figures 7, 9; Plate 4, Figure 8; Plate 5, Figures 1-5, 8; Plate 6, Figures 1, 2, 4, 5, 7, 8; Plate 9, Figure 1)

Dictyocha fibula Ling, 1970, p. 90, Plate 18, Figures 4 to 8 .

Remarks: I omit complete synonymy list of this species, because not all forms assigned to $D$. fibula in previous papers seem to be conspecific with the specimens herein considered as belonging to this species. These specimens are surely conspecific with $D$. fibula as illustrated by Ling from Quaternary and Miocene Pacific sediments.

The main distinctive morphological features of these specimens are the longitudinal position of the apical bar, and the fact that the sustaining spines are either absent or, when they are present, they are situated mostly under the point of junction of the lateral bars to the basal ring, or are displaced a little to the right. In the Quaternary sediments, such forms possess a squarish or slightly rhombic basal ring, with rounded corners, rather long blunt radial horns, and short sustaining spines; the latter being mostly absent (Plate 5, Figure 3; Plate 6, Figures 4,5 ). The size of the basal ring is smaller, and its shape more elongate in some Quaternary samples which are poorer in siliceous microfossils and richer in sapropel (Plate 5, Figure 8; Plate 6, Figures 1, 2).

The Miocene specimens are rather similar to the Quaternary ones. Among them are some specimens which bear an apical spine (Plate 3, Figure 7; Plate 5, Figure 1). Although they might belong to an independent taxon, for instance to $D$. stapedia, they are temporarily assigned to $D$. fibula. It must be pointed out that such an apical spine was never observed in Dictyocha with a transverse apical bar.

Occurrence: Upper (?) Miocene at 124-13-2, $89-90 \mathrm{~cm}$ and Quaternary at 127 and 128 (for details see Figures 2 and 3). 
Dictyocha cf. aspera Lemmermann

(Plate 3, Figure 8; Plate 4, Figures 5 to 7; Plate 7, Figures 4 to 7)

Dictyocha fibula var. aspera Lemmermann, 1901, p. 260, Plate 10, Figures 27 to 28 ; Schulz, 1928, p. 253 , Figure 36a (non 36b). Deflandre, 1950, Figure 26; Dictyocha fibula f. rhombica Desikachary and Maheshwari, 1956, p. 258, Figures 6, 8, 9, 15-18.

Remarks: Specimens of this type were usually assigned by some previous authors to $D$. ausonia Defl. or to $D$. fibula. I think that $D$. fibula var. aspera should be recognized. D. ausonia is only a particular case of it. However, it will continue to be difficult to prove to what extent these two taxa are different from one another, until a detailed study is made of the Italian Miocene silicoflagellates. The specimens recorded in drill-cores are wholly similar to those from Nancoori Island (Indian Ocean), the locality cited by Lemmermann for this species. $D$. aspera is partly similar to $D$. fibula; it differs by the transverse position of its apical bar.

Occurrence: Specimens of the $D$. aspera type were recorded in the upper (?) Miocene of 124-13-2, 89-90 cm, and Quaternary from $128-11-3,148-150 \mathrm{~cm}$.

\section{Dictyocha messanensis - D. aculeata group}

The species of this group are characterized by sustaining spines constantly displaced to the right, and by the longitudinal or oblique position of the apical bar. Based on this characteristic they are evidently among the most highly evolved species of Dictyocha.

Dictyocha messanensis Haeckel

(Plate 8, Figures 8 to 13 ; Plate 9 , Figures 2 to 4 )

Dictyocha messanensis Haeckel, 1862, p. 272, Plate 12, Figures 3 to 6; Dictyocha fibula var. messanensis Gemeinhardt, 1930, p. 51, Figures 41a, c; Gemeinhardt, 1931, p. 42, Figures 8 to 10 ; ?Dictyocha stapedia Haeckel, 1887, p. 1561, Plate 101, Figures 10 to 12; Dictyocha fibula var. stapedia fa. longispina Lemmermann, 1901, p. 261, Plate 10, Figure 25; Schulz, 1928, p. 254, Figure 40.

Remarks: The specimens encountered in the Mediterranean cores are wholly similar to the type specimens described from the Recent waters of the Straits of Messina. It seems that D. stapedia and a series of varieties and forms of D. fibula, which are characterized by an apical spine, also belong to this species.

D. messanensis is the most frequent species in the Quaternary at Sites 127 and 128. Its shape and size vary within small limits, particularly in those samples in which the diatoms are numerous and the percentage of sapropel not too high. In such samples the skeletons are robust. On the other hand, in the samples with a great amount of sapropel and where the assemblage of siliceous microfossils is poor, the skeletons of $D$. messanensis are more delicate and more variable in shape and size. In these cases the specimens seem to be referable to $D$. stapedia.

The apical spine is characteristic for the majority of the specimens. A few forms lacking the apical spine were assigned to this species, these being regarded as individual variations. In the populations with robust skeletons, specimens with additional spines on the lateral bars (Plate 8, Figure 9; Plate 9, Figure 3) are frequent. Extremely rare pentagonal forms (Plate 9, Figure 2) with an apical spine were also encountered.

$D$. messanensis is closely related to $D$. aculeata. They were easily distinguished in the samples investigated not only on the basis of the four additional basal spines, but also because of a difference in size; the skeletons of $D$. messanensis being generally smaller. When both species are similar in size, and the basal additional spines of $D$. aculeata are very short or partly absent, this distinction is much more difficult.

D. messanensis was regarded as a warm-water species by Gemeinhardt, Hovasse and Deflandre, its optimal temperature being considered as $18-20$ degrees, or even 28 degrees. But a more recent study by A. and M. Travers (1968) shows that in the Gulf of Marseille, where it is the most frequent species, its development coincides with the cold seasons, when the water temperature is below 15 degrees. It almost completely disappears during the warm seasons, when it tends to take refuge in deeper waters. It may be possible, on the basis of these data, to conclude that the sequences rich in D. messanensis, and in fact all sapropelitic levels, correspond to cold epochs of the Quaternary, though I am not certain of this

Occurrence: Abundant in the sapropelitic layers at Sites 127 and 128 , where its frequency varies between 50 and 97 per cent.

\section{Dictyocha aculeata Lemmermann \\ (Plate 9, Figures 5 to 10 )}

Dictyocha fibula var. aculeata Lemmermann, 1901, p. 261, Plate 11, Figures 1, 2; Gemeinhardt, 1930, p. 55, Figures 43a,b; Gemeinhardt, 1931, Plate 42, Figures 13, 14; Frenguelli, 1935, Plate 13, Figures 1 to 9; Gleser, 1966, p. 250, Plate 15, Figure 10; Ling, 1970, p. 91, Plate 18, Figures 11 to 13; Dictyocha epiodon (part.) Ehrenberg, 1854, Plate 35B, B, IV, Figure 10; Distephanus japonicus Jouse', 1969, Plate 3, Figures 3, 4.

Remarks: The constant position of the four additional basal horns between the lateral bars and the sustaining spines (the latter is always present to the right of the basal bars) as well as the presence of other additional spines on the basal ring and apical apparatus, are distinctive features of this species. Their constancy throughout the whole Quaternary sequence seems to justify regarding this taxon as an independent species, rather than as a variety as it was considered in the previous papers.

D. aculeata seems to be a Quaternary species, almost all known references being to Recent or Pleistocene occurrences.

The Quaternary specimens of $D$. aculeata from the Mediterranean Sea cores belong to two varieties: a small variety (Plate 9 , Figures 9,10 ) that roughly falls within the dimensions given by Lemmermann (34-38 $\mu$ ) for the type specimens, or by Ling (35-36 $\mu$ ) for those coming from the North Pacific sediments; and a large variety, of about double that size. Gemeinhardt (1930) mentioned similarly variable dimensions $(30-60 \mu)$ for the Atlantic specimens, and Jousé (1969) illustrated a large form from equatorial Pacific sediments.

These two varieties are usually distinct and without intermediate forms, as well as being in a series of other species of silicoflagellates. They are mostly found in the same sample, which creates difficulties in understanding their cause and their systematic rank. In the absence of additional distinguishing characters, they are herein considered as simple varieties of the same species.

Gemeinhardt considered $D$. aculeata a warm-water species, but its occurrence at both low and high latitudes (up to $54^{\circ} 17^{\prime} \mathrm{N}$ in North Atlantic and $33^{\circ} 26^{\prime}-42^{\circ} 36^{\prime} \mathrm{N}$ in North Pacific is not in agreement with this.

Dimensions:

$\begin{array}{lcccc} & \begin{array}{c}\text { Length of } \\ \text { basal } \\ \text { ring }\end{array} & \begin{array}{c}\text { Width of } \\ \text { basal } \\ \text { ring }\end{array} & \begin{array}{c}\text { Length of } \\ \text { axial } \\ \text { horns }\end{array} & \begin{array}{c}\text { Length of } \\ \text { transverse } \\ \text { horns }\end{array} \\ \begin{array}{l}\text { small } \\ \text { variety }\end{array} & 32 \mu & 28 \mu & 6 \mu & 3 \mu \\ & 32 \mu & 28 \mu & 5 \mu & 3 \mu \\ \text { large } & 55 \mu & 53 \mu & 13 \mu & 10 \mu \\ \text { variety } & 54 \mu & 51 \mu & 13 \mu & 11 \mu \\ & 56 \mu & 53 \mu & 8 \mu & 9 \mu \\ & 54 \mu & 52 \mu & 10 \mu & 9 \mu\end{array}$

Occurrence: D. aculeata was recorded, with a low frequency, in almost all Quaternary samples containing siliceous microfossils at Sites 127 and 128 (see Figures 2 and 3)

\section{Genus DISTEPHANUS (Stöhr) Haeckel \\ Distephanus crux (Ehrenberg) \\ (Plate 10, Figures 1, 2)}

Remarks: Rather rare specimens of $D$. crux were found only in the upper (?) Miocene sample 124-13-2, 89-90 cm. The species is completely absent from the Quaternary sediments. In the sample investigated, the specimens have a rounded basal ring, a wide apical ring, and well developed basal horns. The sustaining spines are very short and are displaced to the middle of the space between lateral 
bars and basal horns. The surface of the skeleton is either smooth or covered with visible reticulate ornamentation, particularly on the apical apparatus.

Distephanus speculum (Ehrenberg)

(Plate 10, Figures 4 to 11; Plate 11, Figures 1 to 9 ; Plate 12, Figures 1 to 14 )

Remarks: D. speculum is common in both Miocene at 124-13-2, $89-90 \mathrm{~cm}$, and Quaternary at Sites 127 and 128. The Miocene specimens at Site 124 differ from those of the Quaternary by a wide variability, expressed in size of the basal ring; in size, number, and length of the radial horns; in number of the apical windows; in presence or absence of the sustaining spines; etc. Most frequent, however, are specimens of average size, with a hexagonal basal ring and a single apical window. This wide morphological variability is probably due to the instability of environmental conditions, particularly of the salinity.

The Quaternary specimens at Sites 127 and 128 are, on the contrary, very constant in both size and number of the skeletal elements, the very few variants (less than $1 \%$ ) being mostly abnormal forms (Plate 12, Figures 5 to $7,9,10,13$ ). However, two varieties have been encountered within these stable Quaternary populations: a variety with short radial horns (Plate 12, Figures 7 to $9,13,14)$, and another one with long radial horns (Plate 12, Figure 11). The former is the most frequent, whereas the latter is fairly rare, prevailing only in $128-3-6,97-100 \mathrm{~cm}$.

To this large species might also belong rare pentagonal specimens found in the Quaternary sample 128-10-3, 5-8 cm, and consisting of a robust skeleton armed with five radial horns and a small apical spine originating on a bar of the pentagonal apical window. Their belonging to $D$. speculum, with which they are associated, is doubtful however because of the differences in size and robustness of the skeletons of the two types. Rather similar specimens have been recorded only in $124-13-2,89-90 \mathrm{~cm}$, but there they were members of an extremely variable population of $D$. speculum, whereas in the Quaternary sample, in which they occur, the populations of various silicoflagellate species are characterized by a very limited range of variation.

\section{Distephanus octogonus (Ehrenberg)} (Plate 12, Figures 15 to 19)

Mesocena ? octogona Ehrenberg, 1843 (fide Loeblich et al., 1968, p. 129, Plate 27, Figure 6); Mesocena ? heptagona Ehrenberg, 1843 (fide Loeblich et al., 1968, p. 128, Plate 27, Figure 5); Mesocena binonaria Ehrenberg, 1854, Plate 35A (XVIII), Figure 9; Mesocena bisoctonaria Ehrenberg, 1854, Plate 35A (XVIII), Figure 10; Mesocena polymorpha var. bioctonaria Schulz, 1928, p. 240, Figures 9a-c; Gemeinhardt, 1930, p. 32, Figure 17; Mesocena polymorpha var. biseptenaria Gemeinhardt, 1930, p. 31, Figure 16; Distephanus speculum var. octonarius Gemeinhardt, 1930, p. 69, Figures 59a, b; Distephanus speculum var. polyactis Gemeinhardt, 1930, p. 71, Figure 60; Distephanus octonarius Hovasse, 1932, Plate 6, Figures 1 to 22; Dictyocha octonaria Bachmann and Schrader, 1962, Plate 2, Figure 15; Jerkovic, 1969b, Plate 23, Figures 1, 2; Plate 24, Figures 1, 2; Dictyocha speculum Frenguelli, 1940, p. 52, Figures 7a, b; Dictyocha sp. Frenguelli, 1940, p. 52, Figure 7e; Octatis pulchra Schiller, 1925 (fide Loeblich et al., 1968, pp. 59, 136, Plate 32, Figure 1).

Description: Basal ring usually with seven to nine (most frequently eight) basal horns; apical ring a little smaller than the basal ring, made of delicate bars tending to disappear, in which case the skeleton consists only of a basal ring with basal horns and short, almost perpendicular lateral bars. No sustaining spines, nor superficial ornamentation.

Dimensions: Diameter of the basal ring without basal horns 23-26 $\mu$.

Remarks: It is customary to ascribe specimens answering the above description to Dictyocha octonaria, a species erected by Ehrenberg in 1844 and illustrated only in 1901 by Lemmermann as Distephanus octonarius. The specimen illustrated by Lemmermann under this name does not appear to be conspecific with $D$. octogonus, because of its apical ring, which is small and shows no trend toward reduction as the latter does. I insist upon this trend, for it is one of the distinctive features of this species. But even if they were conspecific, $D$. octogonus has priority over $D$. octonarius. Ehrenberg's Mesocena? heptagona and $M$. ? octogona are doubtless simple mesocenoid variants of the same species. Under the circumstances it seems preferable to choose the latter form as type, because such octogonal skeletons are the most frequent in the populations of this species.

Stratigraphic range: All the above synonymy list refers to Quaternary forms. Thus $D$. octogonus seems to be restricted to this period, although its existence in Pliocene is not excluded.

Occurrence: Rather rare at Sites 127 and 128 (Figures 2 and 3).

\section{Genus CANNOPILUS Haeckel}

Cannopilus sp.

(Plate 12, Figure 20)

The Quaternary sediments lack Cannopilus, and even the Miocene at $124-13-2,89-90 \mathrm{~cm}$ proved to be extremely poor in this genus. The only representative found in this sample is the illustrated broken specimen. It has an apical apparatus wholly similar to that of C. sphaericus Gemeinh., but its basal ring lacks radial horns. The three spines (the entire skeleton had perhaps six or seven) seem to be sustaining spines, rather than radial horns. By its aspect this specimen appears to belong to a new species, probably intermediate between $C$. sphaericus and $C$. jouseae Bach.

\section{INCERTAE SEDIS \\ Genus PSEUDOROCELLA Deflandre \\ Pseudorocella corona Deflandre \\ (Plate 1, Figure 7)}

Pseudorocella corona Deflandre, 1946, p. 337, Figure 4; Stradner, 1961, p. 92, Plate 3, Figures 105, 106; Bachmann et al., 1963, p. 154, Plate 20, Figure 82; Ichikawa et al., 1967, pp. 144, 154, Plate 1; Figures 1 to 9; Plate 2, Figures 1 to 23.

Remarks: A single specimen of this species was found in $124-13-2,89-90 \mathrm{~cm}$.

\section{REFERENCES}

Bachmann, A., 1964. Part II Silicoflagellidae und Archaeomonadaceae. In Ichikawa, W., N. Fuji and A. Bachmann, 1964. Fossil diatoms, pollen grains and spores, silicoflagellates and archaeomonads in the Miocene Hojuji diatomaceous mudstones, Noto Peninsula, Central Japan. Sc. Repts. Kanazawa Univ. 9 (1), 87, pls. 1-7.

, 1970a. Silicoflagellaten aus dem oberösterreichischen Egerien (Oberoligozän). Verh. Geol. Bundesanst. H. 2, pp. 275-305, pls. 1-7, text-figs. 1-3. 1970 b. Catalogus fossilium Austriae. H. Ib, Flagellata (Silicoflagellata). Wien, pp. 1-28.

Bachmann, A. and Ichikawa, W., 1962. The silicoflagellides in the Wakura Beds, Nanao City, Prefecture Ishikawa, Japan. Sc. Repts. Kanazawa Univ. 8 (1), 161, pls. 1-10.

Bachmann, A. and Schrader, H. J., 1962. Die Kieselorganismen im Peru-Guano. Mikrokosmos. 51 Jg., H. 3, pp. 74-77, pls. 1, 2.

Bachmann, A., Papp, A. and Stradner, H., 1963. Mikropaläontologische .Studien im "Badener Tegel" von Frättingsdorf N. O. Mitt. Geol. Gesel. Wien. 56, (f. 1), 117 , pls. 1-24.

Bachmann, A. and Papp, A., 1968. Vorkommen und Verbreitung der Silicoflagellaten im Neogen Österreichs. Giorn. Geol., Bologna, ser. 2, 35 (f. 2), 117, pl. 3.

Carnevale, P., 1908. Radiolarie e silicoflagellati di Bergonzano (Reggio Emilia). Mem. R. Inst. Veneto Sci., Lett., Arti. 28 (3), 1, pls. 1-4. 
Deflandre, G., 1932a. Sur la systématique des silicoflagellés. Bull. Soc. Bot. France. 79, 494, 42 figs. 1932b. Les silicoflagellés des terres fossiles à diatomées. Bull. Soc. franc. Microscopie. 1, 10, 60 figs. , 1940. Sur une structure réticulée méconue du squelette des silicoflagellidés. C. R. Acad. Sc. Paris. 211, 597, figs. 1-7. 1946. Phyllodictyocha nov. gen. Silicoflagellidés et formes affines du Miocène de Hongrie. Bull. Soc. Bot. France. 93 (9), 335, figs. 1-5. 1950. Contribution à l'étude des Silicoflagellidés actuels et fossiles. Microscopie. 2, 1, 243 figs.

Desikachary, T. V. and Maheshwari, C. L., 1956. Fossil silicoflagellates from Colebrook and Nancoori Islands. $J$. Indian Bot. Soc. 35, 257, figs. 1-19.

Ehrenberg, C. G., 1854. Mikrogeologie. Leipzig, pp. 1-31, pls. 1-40.

Frenguelli, J., 1935. Variaciones de Dictyocha fibula en el golfo de San Matias (Patagonia Septentrional). An. Mus. Argent. Cienc. Nat. "Bernardino Rivadavia". 38 (4), 265, pls. 1-14.

, 1940. Consideraciones sobre los silicoflagellados fossiles. Rev. Mus. La Plata. n. ser. 2, (Paleontol. no. 7), 37,38 figs.

Gemeinhardt, K., 1930. Silicoflagellatae. L. Rabenhorst's Kryptogamen-flora. 10 (2), 1, 69 figs., pl. 1.

1931. Die Silicoflagellaten der deutsche SüdpolarExpedition 1901-1903. Deutsche Südpolar-Expedition, Forsch. u. Ergeb. 1901-1903. 20 (Zool. vol. 12), 221, pls. 42,43 .

Gleser, S. I., 1966. Silicoflagellatophyceae. Flora Plantarum Cryptogamarum. Acad. Sc. USSR, Inst. Bot. 7, 1, pls. 1-33.

Hays, J. D., Saito, T., Opdyke, N. D., and L. H. Burkle, 1969. Pliocene-Pleistocene sediments of the equatorial Pacific: their paleomagnetic, biostratigraphic and climatic record. Bull. Geol. Soc. Am. 80, (8), 1481, figs. 1-16, pl. 1 .

Hovasse, R., 1932. Contribution à l'étude des Silicoflagellés. Multiplication, variabilité, hérédité, affinités. Bull. Biol. France Belgique. 66, (f. 4), 448, figs. 1-11, pls. 1,2 .
Ichikawa, W., Shimizu, I. and Bachmann, A., 1967. Fossil silicoflagellates and their associated uncertain forms in Iida Diatomite, Noto Peninsula, Central Japan. Sc. Repts. Kanazawa Univ. 12, 143, pls. 1-9.

Jerkovic, L., 1969a. Les Silicoflagellidés fossiles des environs de Zagreb, de Bosanska Kostajnica et de Derventa (Jugoslavie). Godis. Biol. Inst. Univ. Sarajevo. 22, 21, figs. 1-239, pls. 1-12. 1969b. Les nouvelles recherches de la superficie du squelette des Silicoflagellidés. God. Biol. Inst. Univ. Sarajevo. 22, 129, pls. 1-28.

Jousé, A. P., 1969. Silicoflagellates in bottom sediments of Pleistocene and Late Pliocene of the Pacific Ocean. In Micropaleontology and organogenous sedimentation in the oceans. Nauka. Moscow, pp. 105-114, 4 figs.

Lemmermann, E., 1901. Silicoflagellatae. Ber. deutsch. bot. Gesel. pp. 247-271, pls. 10, 11.

Ling, Hsin-Yi, 1970. Silicoflagellates from central North Pacific core sediments. Bull. Amer. Paleont. 58, (259), 81 , pls. $18-20$, text-figs, $1-5$.

Loeblich, A. R., III, Loeblich, L. A., Tappan, H., and Loeblich, A. R., Jr., 1968. Annotated index of fossil and Recent silicoflagellates and ebridians with description illustrations of validly proposed taxa. Geol. Soc. Am., Mem. 106, pp. I-XI + 1-319, pls. 1-53, text-figs. 1-21

Mandra, Y. T., 1968. Silicoflagellates from the Cretaceous, Eocene and Miocene of California, USA. Proc. Calif. Acad. Sc. Ser. 4, 36 (9), 231, figs. 1-83.

Muhina, V. V., 1969. Biostratigraphy of sediments and some questions of paleogeography of the tropical region of the Pacific and Indian Oceans. In Micropaleontology and organogenous sedimentation in the oceans. Nauka. Moscow, pp. 52-84.

Schulz, P., 1928. Beiträge zur Kenntniss fossiler und rezenter Silicoflagellaten. Bot. Archiv. 21225.

Stradner, H., 1961. Über fossile Silicoflagellaten und die Möglichkeit ihrer Verwendung in der Erdölstratigraphie. Erdöl u. Kohle. 14 (no. 2), 87, pls. 1-3.

Travers, A. and Travers, M., 1968. Les silicoflagelle's du golfe de Marseille. Marine Biology. 1, 285.

Tynan, E. J., 1957. Silicoflagellates of the Calvert formation (Miocene) of Maryland. Micropaleontology.3 (no. 2), 127, pl. 1, figs. 1-3. 


\section{PLATE 1}

Miocene and Quaternary Silicoflagellates (All figures $\times 835$ )

Figures 1, 2, 4-6. Mesocena elliptica verrucosa n. ssp., Quaternary; Figures 1, 6, specimens with typical superficial ornamentation; Figure 1, 128-10-3, 59-62 cm; Figures 2, 5, 128-10-3, 5-8 cm; Figure 4, 128-11-3, 148-150 $\mathrm{cm}$; Figure 6, 128-10-3, 143-146 cm.

Figure 3. Mesocena elliptica diodon Ehr., Miocene, 124-13-2, $89-90 \mathrm{~cm}$.

Figure 7. Pseudorocella corona Defl., Miocene, 124-13-2, 89-90 $\mathrm{cm}$. 
PLATE 1

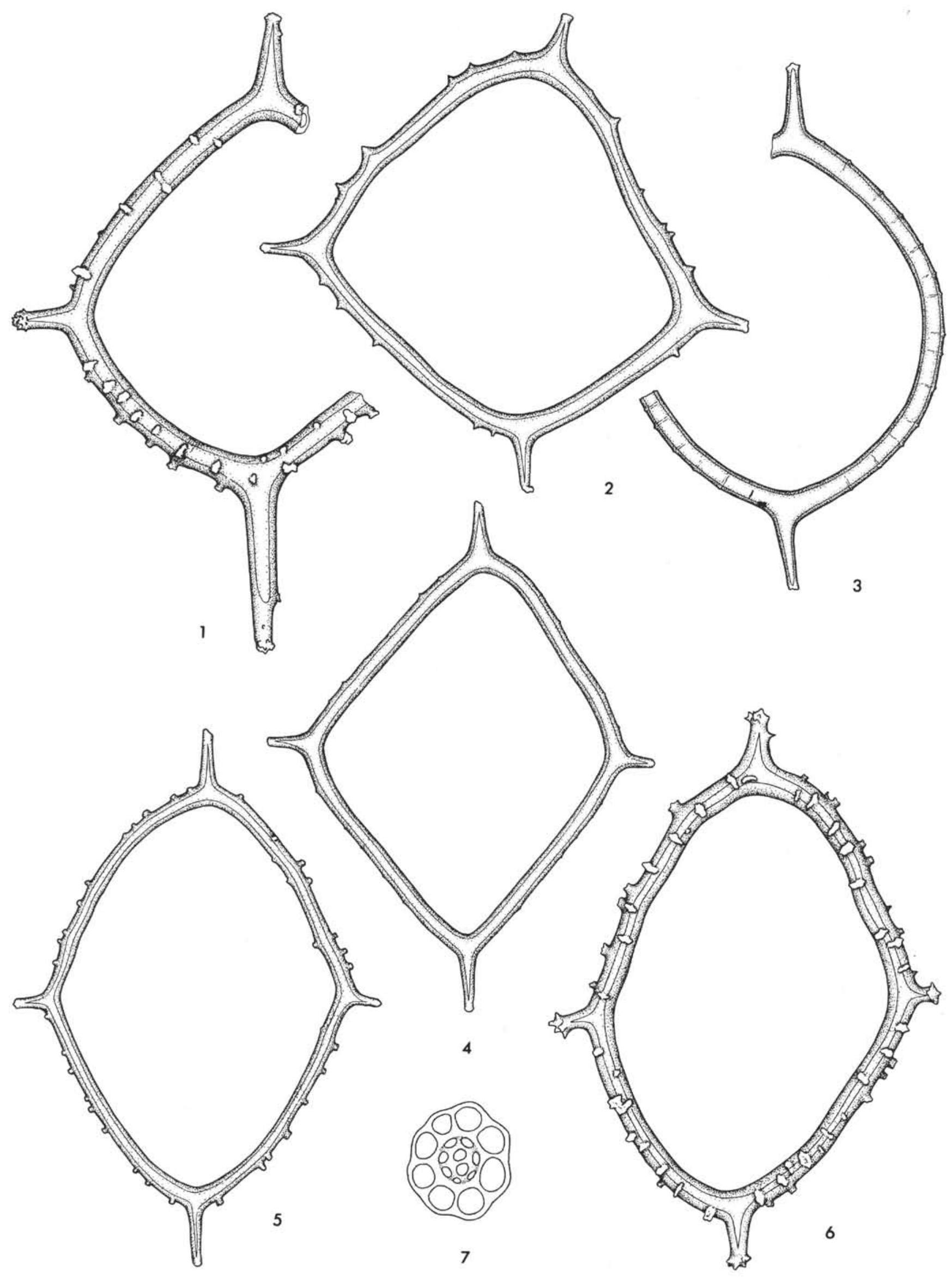




\section{PLATE 2}

Miocene and Quaternary silicoflagellates (All figures X835)

Figures 1-6. Mesocena elliptica verrucosa n. ssp.; Figure 1, hornless specimen with typical ornamentation, Miocene, 124-13-2, 89-90 cm; Figures 2 to 6, Quaternary; Figures 2 to 4 , specimens with typical ornamentation; Figure 2, 128-10-3, $5-8 \mathrm{~cm}$; Figures 3, 4, 128-10-3, $143-146 \mathrm{~cm}$; Figure 5, 128-11-3, 148-150 cm; Figure $6,127-14-5,20-21 \mathrm{~cm}$. 
PLATE 2
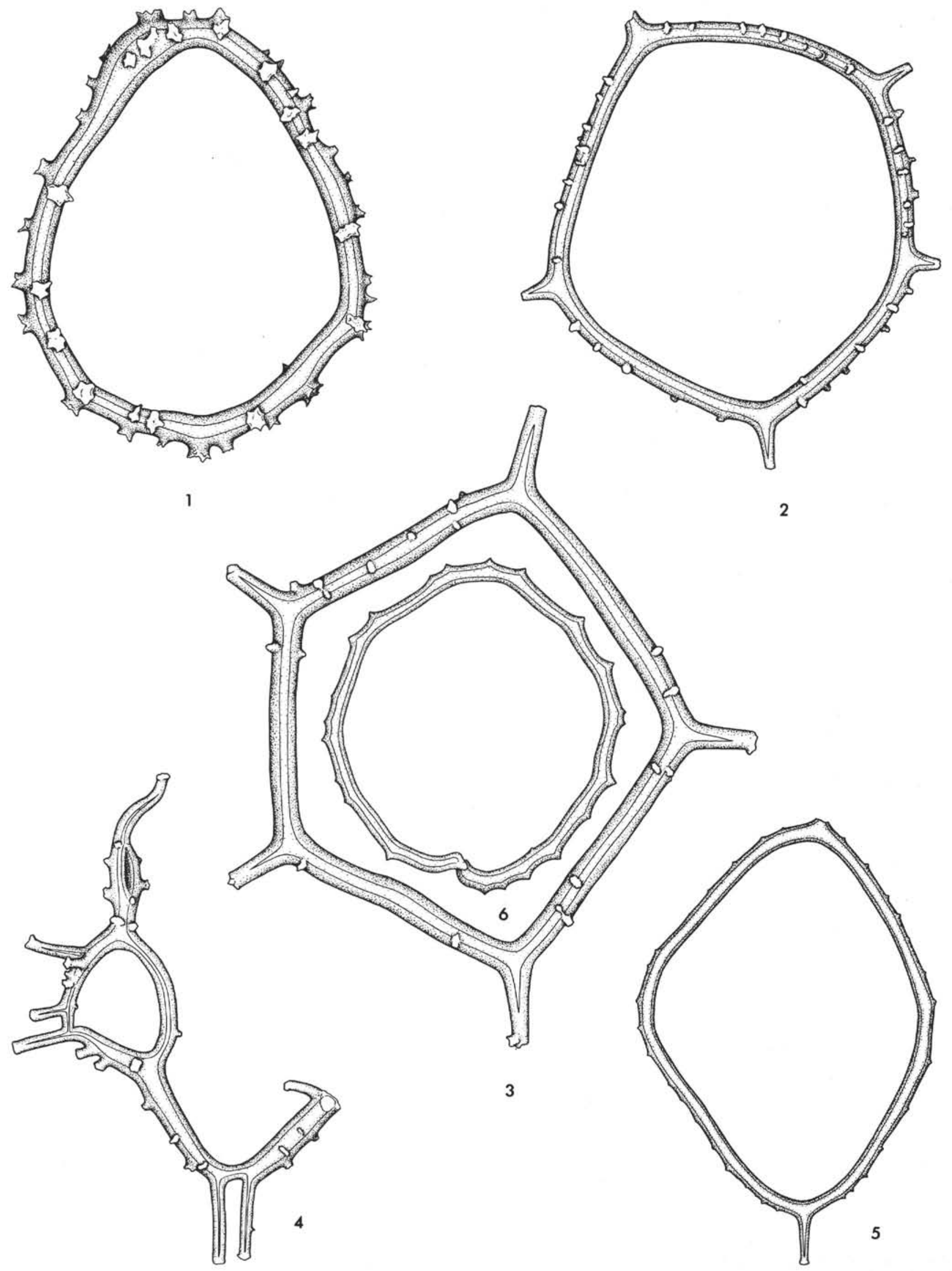


\section{PLATE 3}

Miocene and Quaternary silicoflagellates (All figures $\times 835$ )

Figures 1, 3, 5, Mesocena elliptica verrucosa n. ssp., Quaternary; 6. Figures 1, 3, specimens with typical ornamentation; Figure 1, 128-10-3, 5-8 cm; Figure 3, 128-10-3, $143-146 \mathrm{~cm}$; Figures 5, 6, 128-11-3, 148-150 cm.

Figure 4. Mesocena elliptica elliptica Ehr., with reticulate ornamentation, Miocene, $12413-2,89-90 \mathrm{~cm}$.

Figure 2. Mesocena apiculata (Schulz) Defl., Miocene, 124-13-2, 89-90- cm.

Figures 7-9. Dictyocha fibula Ehr., Miocene, 124-13-2, 89-90 cm.

Figure 8. Dictyocha cf. aspera Lemm., Miocene, 124-13-2, $89-90 \mathrm{~cm}$. 
PLATE 3

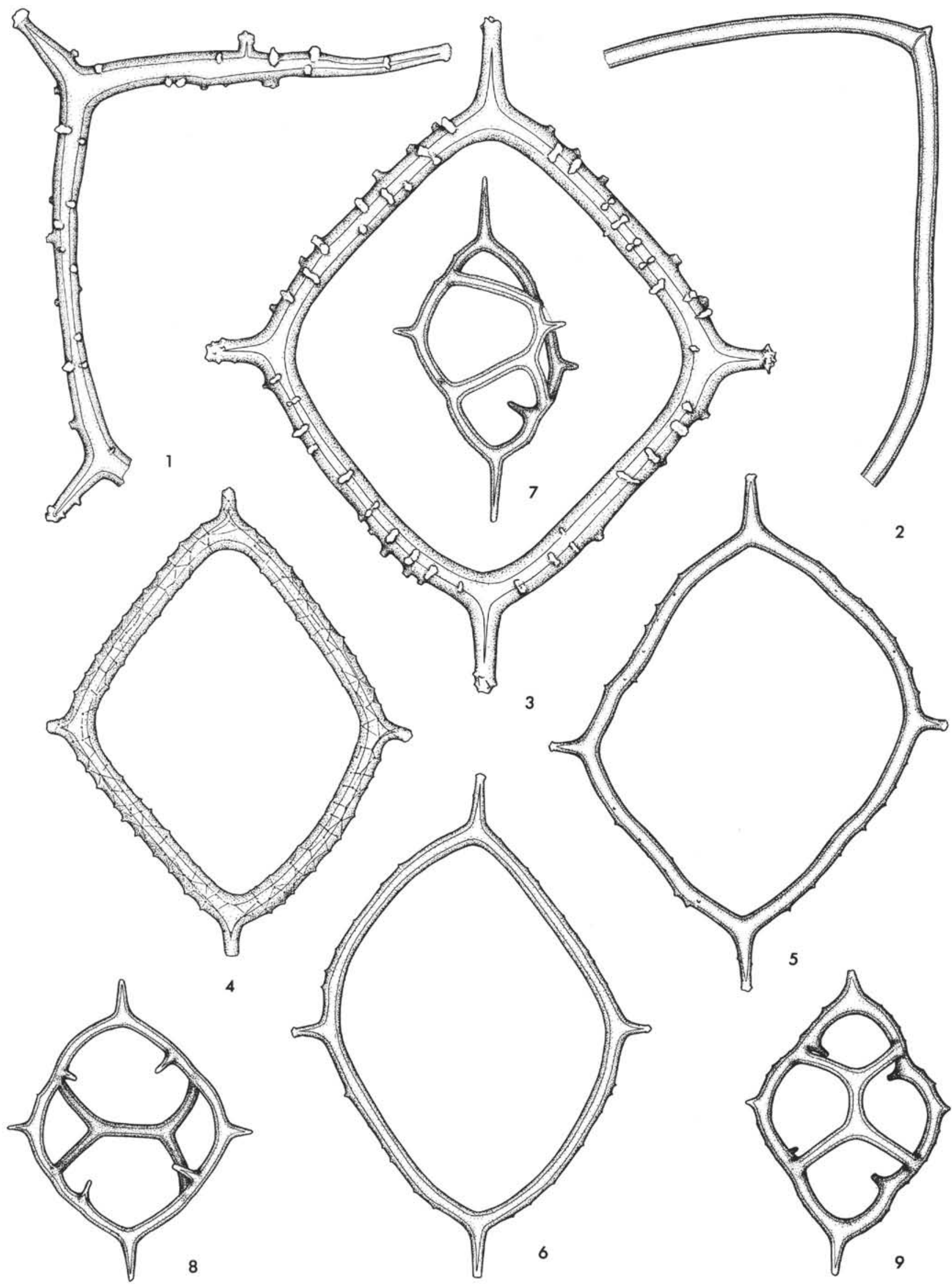


PLATE 4

Miocene silicoflagellates (All figures $\times 835$ )

Figures 1, 2. Naviculopsis biapiculata (Lemm.), Miocene, 124-13-2, $89-90 \mathrm{~cm}$.

Figure 3. Naviculopsis cf. lata (Defl.), Miocene, 124-13-2, $89-90 \mathrm{~cm}$.

Figure 4. Naviculopsis sp., Miocene, 124-13-2, $89-90 \mathrm{~cm}$.

Figures 5-7,9. Dictyocha cf. aspera Lemm., Miocene 124-13-2, $89-90 \mathrm{~cm}$; Figure 9, mutant similar to D. ausonia Defl.

Figure 8. Dictyocha fibula Ehr., double skeleton, Miocene, 124-13-2, $89-90 \mathrm{~cm}$. 
34.2. SILICOFLAGELLATES

PLATE 4
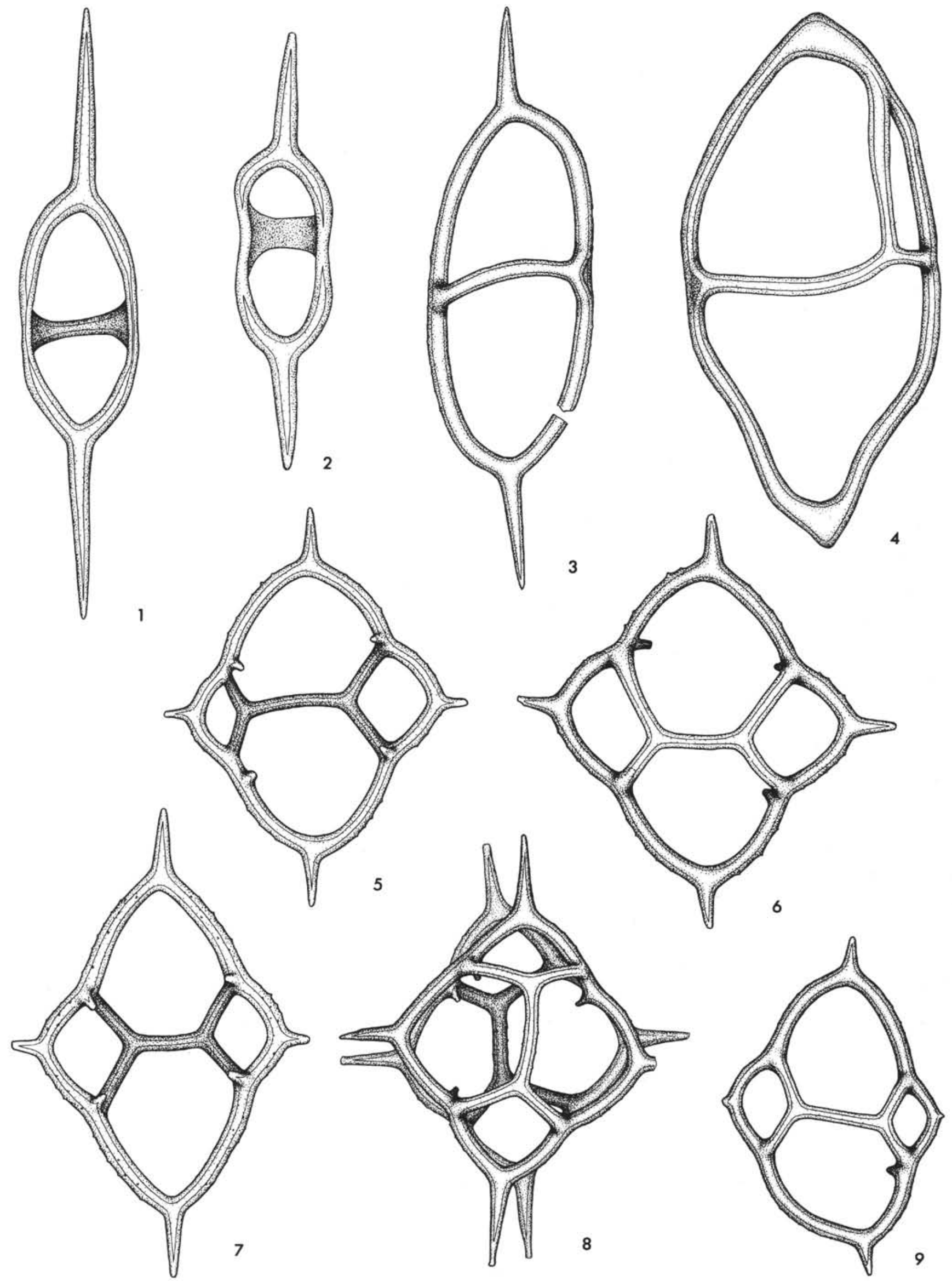


\section{PLATE 5}

Miocene and Quaternary silicoflagellates (All figures X835)

Figures 1-5, 8. Dictyocha fibula Ehr.; Figures 1, 2, Miocene, 124-13-2, 89-90 cm; Figures 3-5, 8, Quaternary; Figure 3, 128-11-3, 148-150 cm; Figures 4, 5, pentagonal forms, $127-14-5,54-56 \mathrm{~cm}$; Figure 8 , $128-3-5,41-44 \mathrm{~cm}$.

Figures 6,7. Dictyocha sp. (abnormal forms of D. brachyacantha ?); Figure 6, 128-10-3, 143-146 cm; Figure 7, $128-10-3,59-62 \mathrm{~cm}$. 
PLATE 5

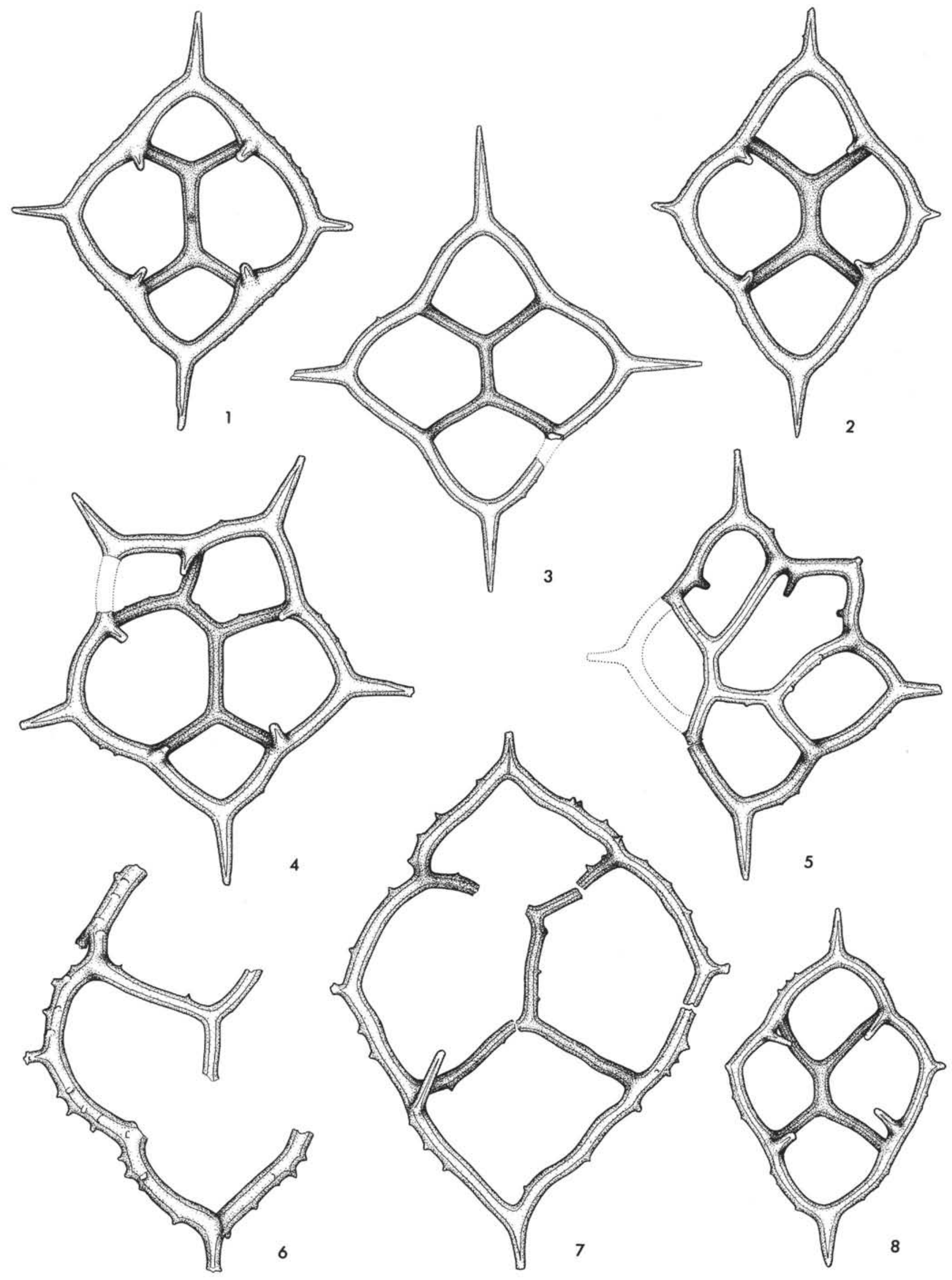




\section{PLATE 6}

Miocene and Quaternary silicoflagellates (All figures $\times 835$ )

Figures 1, 2, 4, Dictyocha fibula Ehr., Quaternary; Figures 1, 2, 7,8 128-3-5, 41-44 cm; Figures 4, 8, 128-10-3, 143-146 $\mathrm{cm}$; Figure 5, 128-11-3, 148-150 cm; Figure 7, $128-10-3,5-8 \mathrm{~cm}$.

Figures 3, 6. Dictyocha brachyacantha n. sp., Miocene, 124-13-2, $89-90 \mathrm{~cm}$. 
PLATE 6

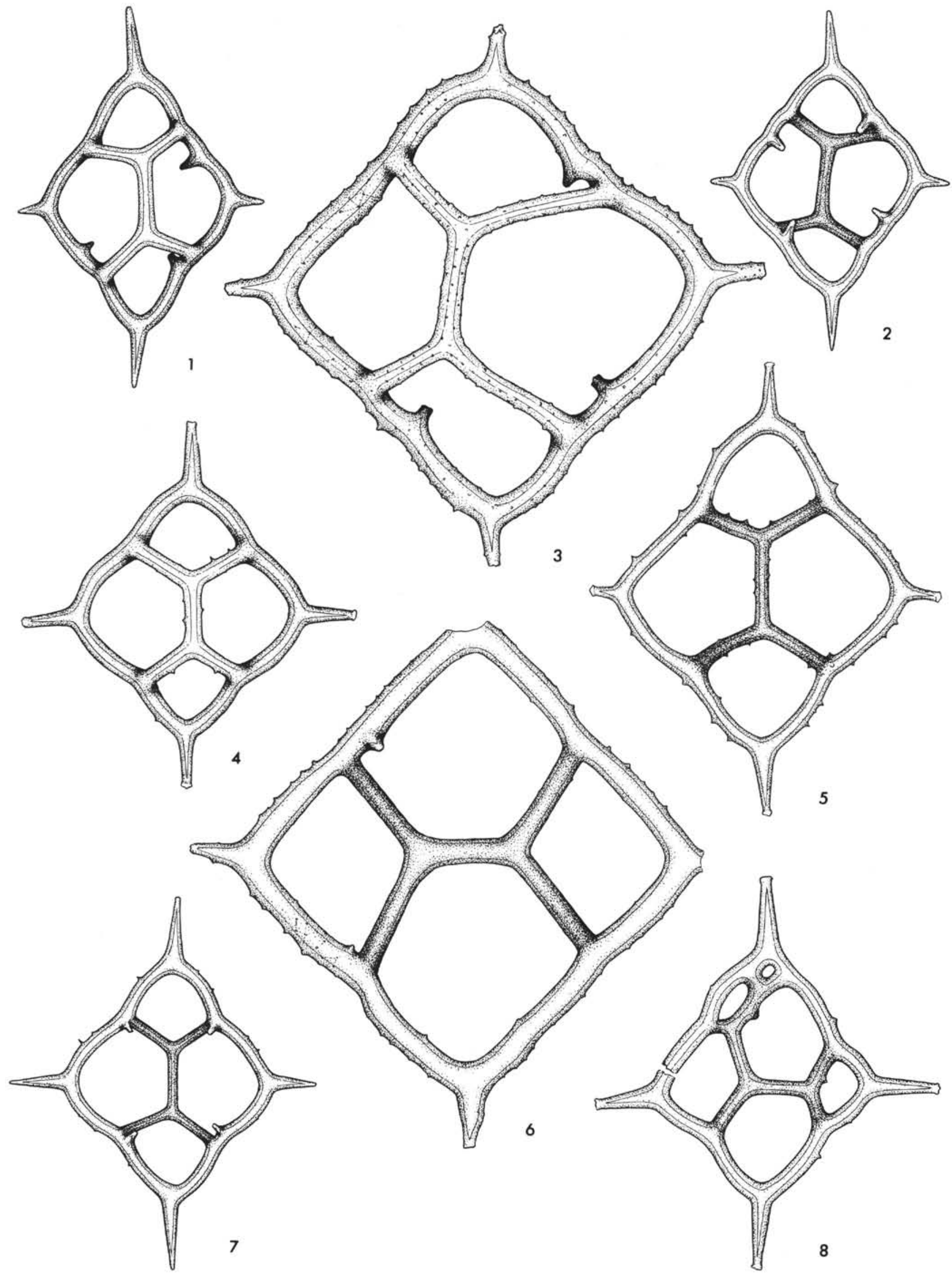


P. DUMITRICA

\section{PLATE 7}

Quaternary silicoflagellates (All figures $\times 835$ )

Figures 1-3. Dictyocha brachyacantha n. sp., 128-11-3, $148-150 \mathrm{~cm}$.

Figures 4-7. Dictyocha cf. aspera Lemm., 128-11-3, 148-150 cm. 
PLATE 7

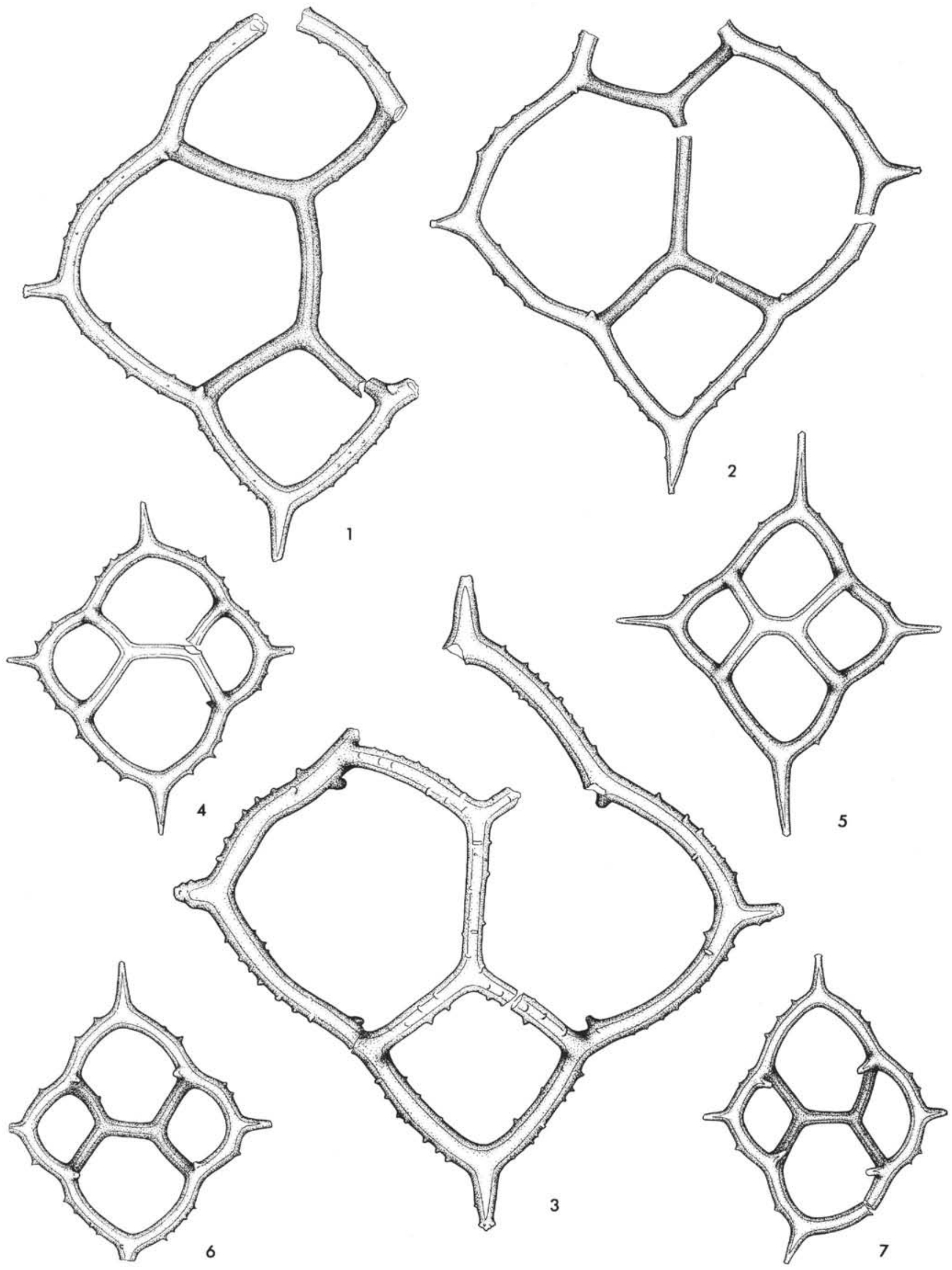




\section{PLATE 8}

Quaternary silicoflagellates (All figures X835)

Figures 1-7. Dictyocha lingi n. sp., 128-11-3, 148-150 cm.

Figures 8-13. Dictyocha messanensis Hckl.; Figures 8, 12, 128-10-3, $5-8 \mathrm{~cm}$; Figure 9, 128-8-1, $134137 \mathrm{~cm}$; Figure 10, 128-10-3, 59-62 cm; Figure 11, 128-3-5, $41-44 \mathrm{~cm}$; Figure 13, 128-3-6, 67-71 cm. 
PLATE 8
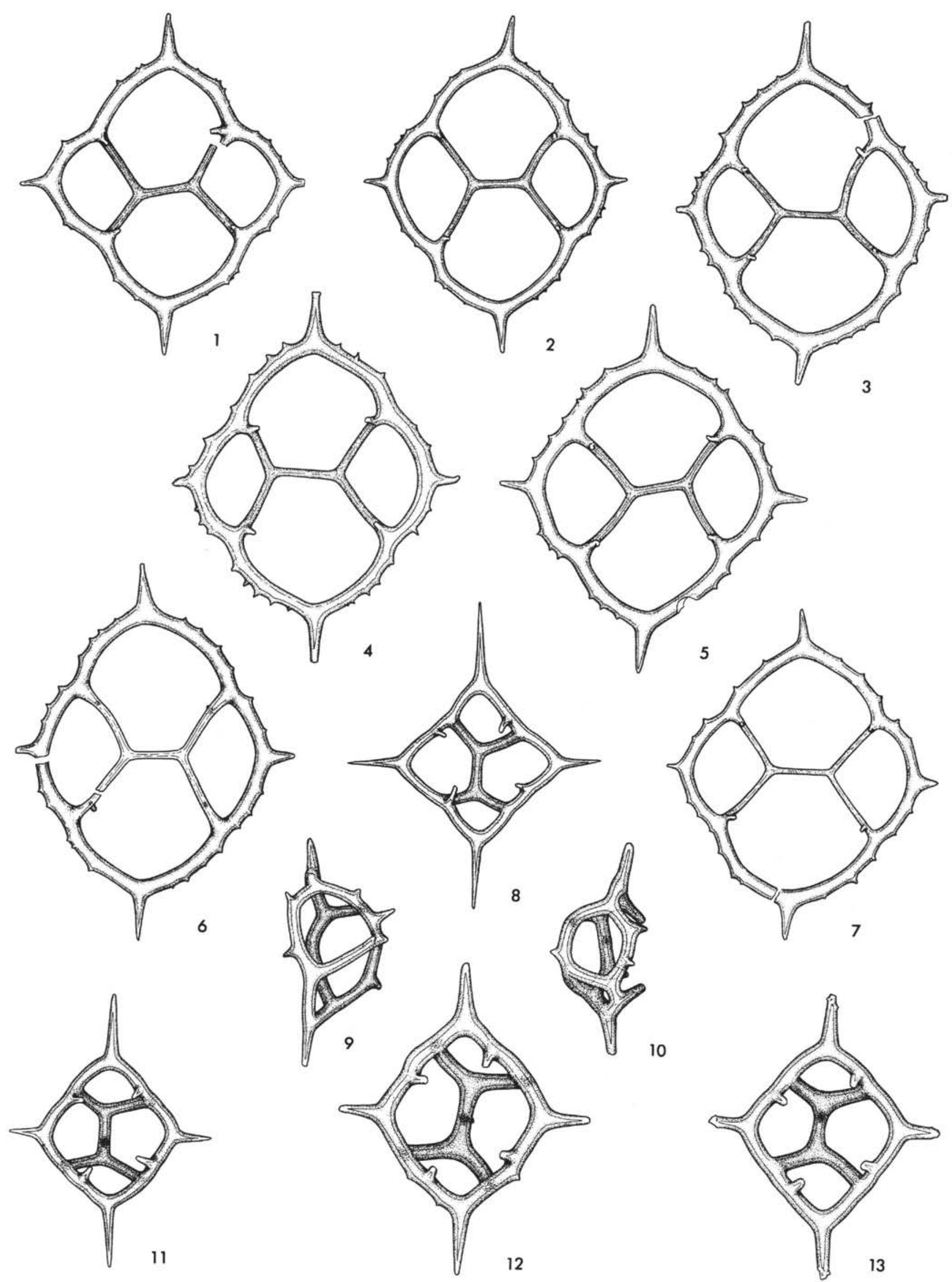
PLATE 9

Quaternary silicoflagellates (All figures $\times 835$ )

Figure 1. Dictyocha fibula $\mathrm{Ehr} ., 128-3-5,5-8 \mathrm{~cm}$.

Figures 2-4. Dictyocha messanensis Hckl.; Figure 2, pentagonal specimen, 128-11-3, 148-150 cm; Figure 3, lateral view, 128-8-1, 105-108 cm; Figure 4, lateral view, $127-14-5,54-56 \mathrm{~cm}$.

Figures 5-10. Dictyocha aculeata Lemm.; Figures 5 to 8, large forms; Figures 9 and 10, small forms; Figures 5 to 7, $128-3-6,120-123 \mathrm{~cm}$; Figure $8,128-3-5,5-8 \mathrm{~cm}$; Figures 9, 10, 128-3-5, 41-44 cm. 
PLATE 9

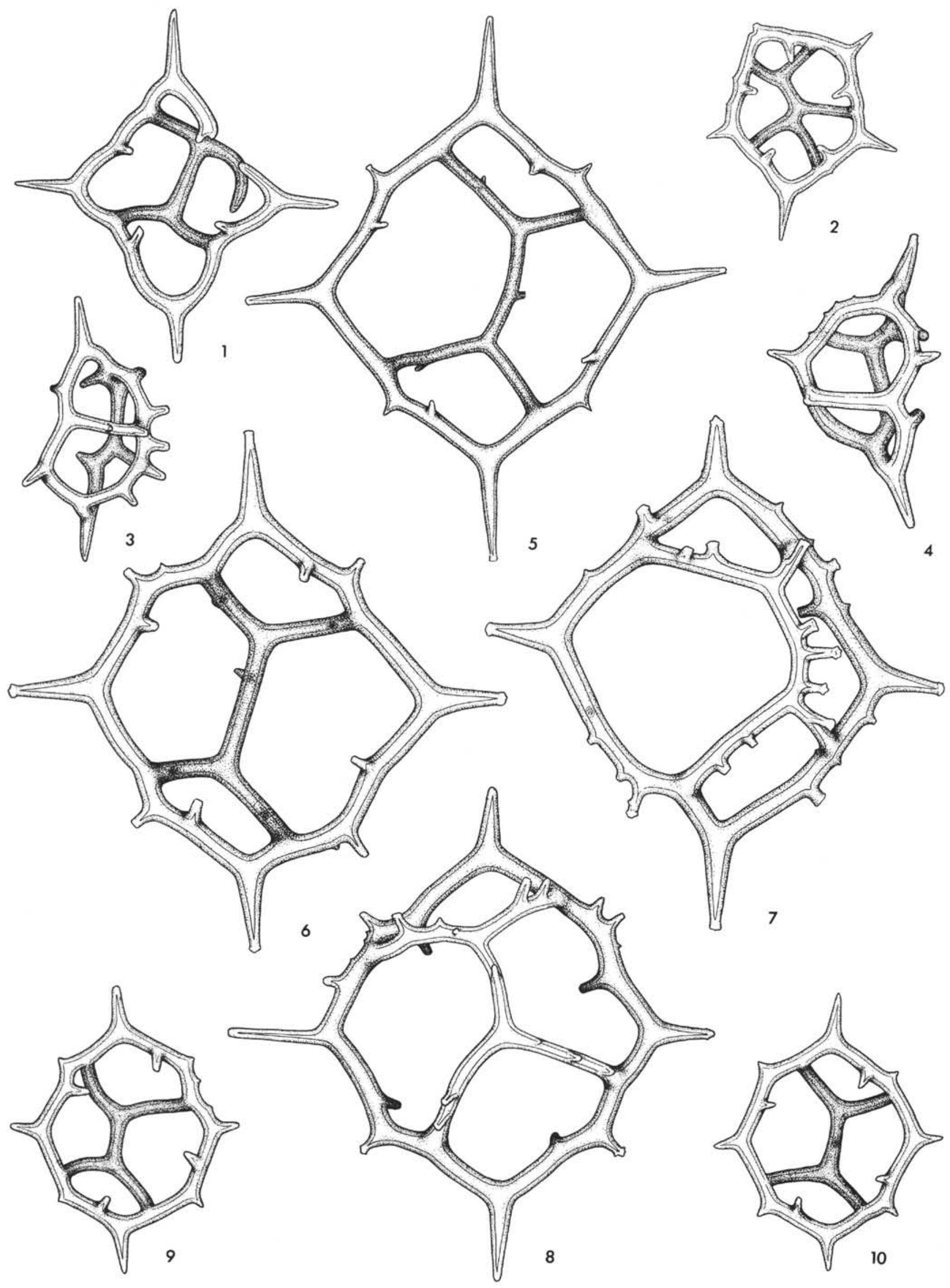




\section{PLATE 10}

Miocene and Quaternary silicoflagellates (All figures X835)

Figures 1,2. Distephanus crux (Ehr.), Miocene, 124-13-2, $89.90 \mathrm{~cm}$.

Figure 3. Distephanus speculum ? fa. pentagona, Quaternary, $128-10-3,5-8 \mathrm{~cm}$.

Figures 4-11. Distephanus speculum (Ehr.), Miocene, 124-13-2, $89.90 \mathrm{~cm}$. 
PLATE 10

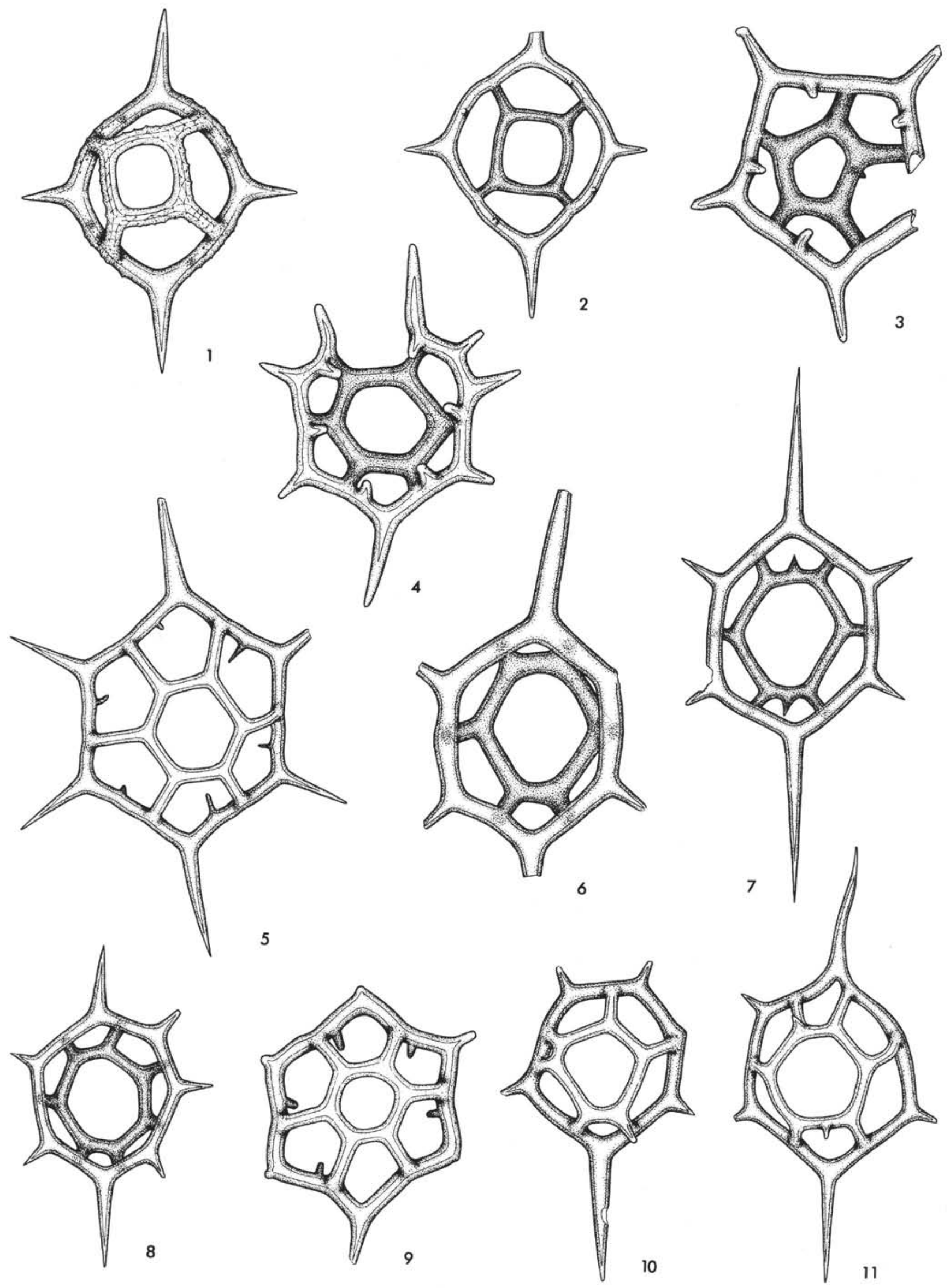


PLATE 11

Miocene silicoflagellates (All figures $\times 835$ )

Figures 1-9. Distephanus speculum (Ehr.), 124-13-2, 89-90 cm. 
PLATE 11
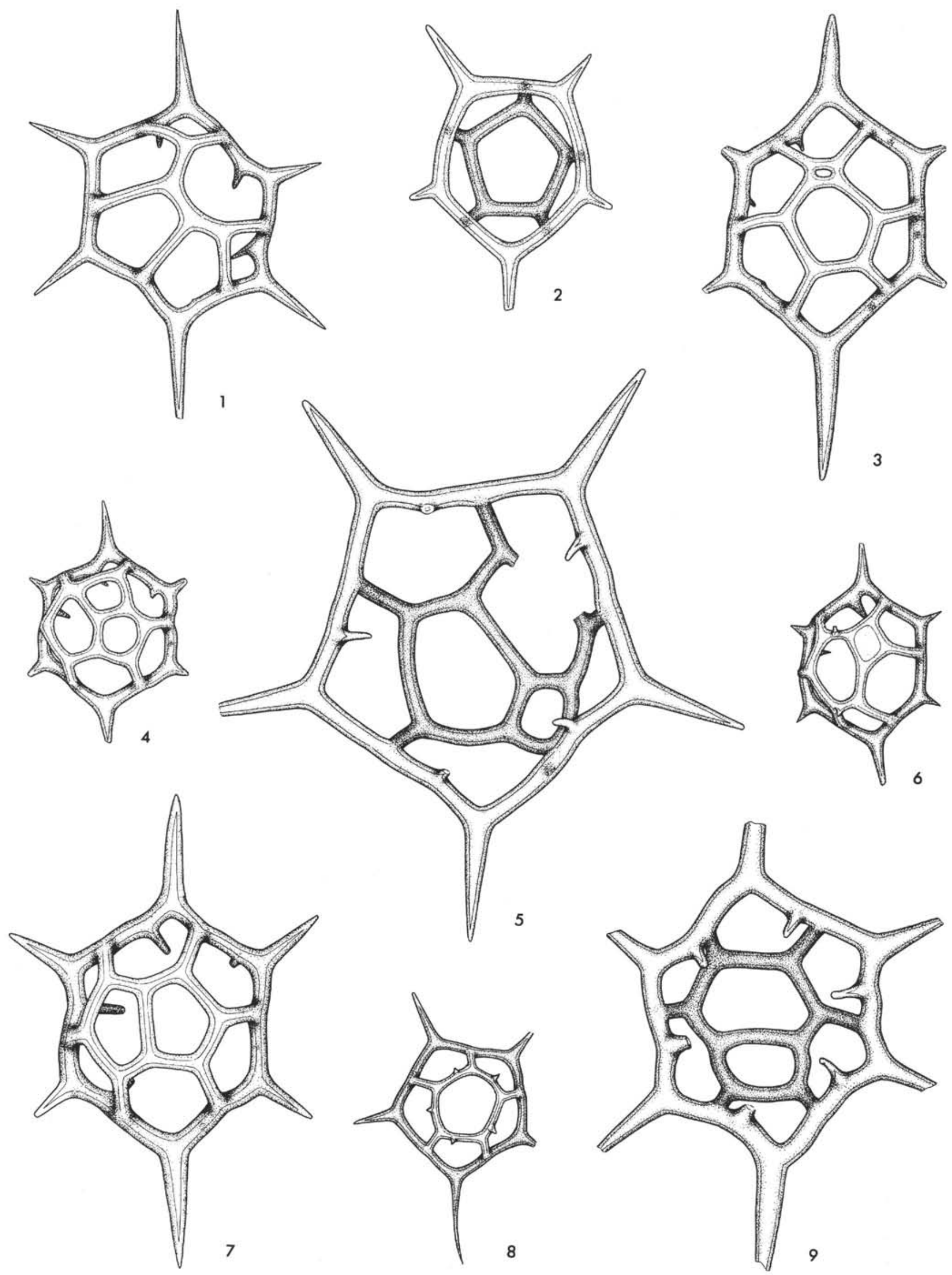


\section{PLATE 12}

Miocene and Quaternary silicoflagellates (All figures $\times 835$ )

Figures 1-14. Distephanus speculum (Ehr.); Figures 1 to 4, Miocene, 124-13-2, $89-90 \mathrm{~cm}$; Figures 5 to 14, Quaternary; Figure 5, 128-3-5, $41-44 \mathrm{~cm}$; Figures 6,8 to 10 , $14,128-10-3,5-8 \mathrm{~cm}$; Figures 7, 13, 128-3-6, 97-100 $\mathrm{cm}$; Figure 11, 128-3-6, 107-110 cm; Figure 12, $128-10-3,59-62 \mathrm{~cm}$.

Figures 15-20. Distephanus octogonus (Ehr.), Quaternary; Figures 15 to $18,128-11-3,148-150 \mathrm{~cm}$; Figure 19, 128-10-3, $78.81 \mathrm{~cm}$; Figure 20, Cannopilus sp., Miocene, $124-13-2,89-90 \mathrm{~cm}$. 
PLATE 12
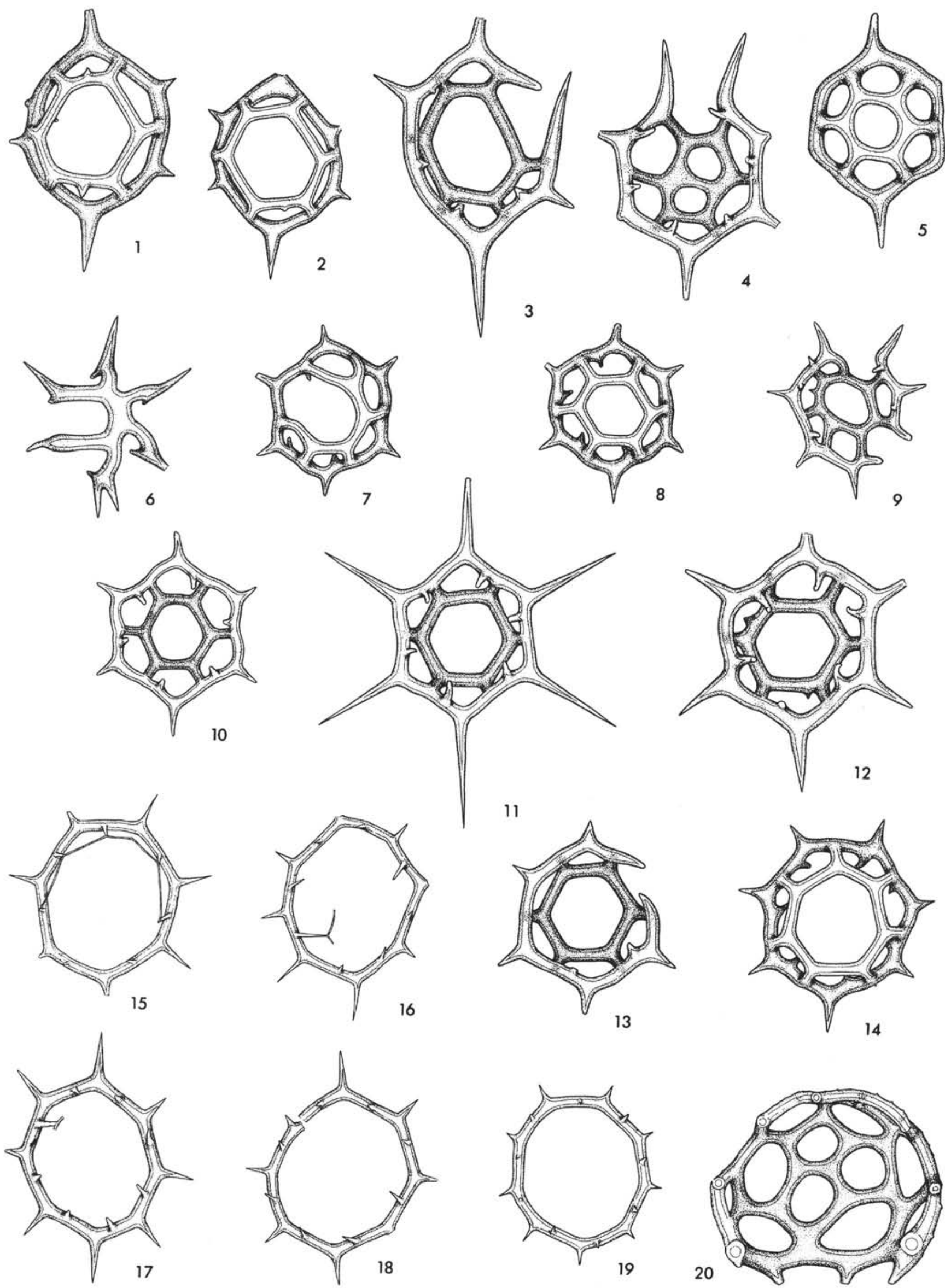

13

14 